\title{
A República e a Descoberta da América: Nova Forma de Governo e Mudança Identitária no Brasil da Década de $1890^{*}$
}

\author{
Bernardo Ricupero \\ Universidade de São Paulo (USP), São Paulo, SP, Brasil. E-mail: bernardor@usp.br
}

Como o Brasil se sul-americanizou

depressa, e com que fúria.

(Joaquim Nabuco, 1893)

osé Veríssimo resenha Ariel já em 1900, ano da publicação do opús-
culo․ . Destaca como "é mais um sintoma do despertar do sentimen-
to latino, ou antes do sentimento espanhol na porção ibérica da Améri-
ca" (Veríssimo, 1902:395), o que teria sido estimulado principalmente
pela guerra entre a Espanha e os EUA dois anos antes. Faz a ressalva,
porém, que não existiria propriamente nesses países "opinião públi-
ca", já que a maior parte das suas populações seria muito pobre e igno-
rante. Mesmo assim, defende que a mensagem de José Enrique Rodó
seria democrática, resguardando, entretanto, assim como o escritor
uruguaio, a necessidade de a multidão, identificada com Caliban, ser
dirigida por aqueles da estirpe de Próspero. No que se refere ao Brasil,
apesar de proclamar acreditar na fraternidade latino-americana, suge-
re que o livro não teria maior apelo no país. Indica que o motivo de tal
acolhida se daria em razão do "que um vigoroso publicista nosso"
(ibidem:397) chamou de "ilusão americana" ser especialmente forte no

* Agradeço a leitura atenta e os comentários pertinentes de Rubens Ricupero, Christian
Lynch e dois pareceristas anônimos de DADOS - Revista de Ciências Sociais. Não preciso
dizer que eventuais defeitos do texto são de minha inteira responsabilidade.

DADOS - Revista de Ciências Sociais, Rio de Janeiro, vol. 61, noำ 2018, pp. 213 a 253.

http://dx.doi.org/10.1590/001152582018151 
Brasil; ou seja, a atração pelos EUA - a nordomania para a qual Rodó tinha alertado -, não encontraria maior resistência em terras tupiniquins.

A recepção brasileira a Ariel é, desde o início, ambígua. Por um lado, um crítico como Veríssimo enfatiza que sua mensagem se refere especialmente à América hispânica. Por outro, é significativo como, já no ano de sua publicação, o opúsculo de Rodó é discutido no país.

É o novo contexto republicano que abre caminho para que haja no Brasil interesse por Ariel e, de maneira geral, pela América. Em contraste com o Império, que se servira especialmente de referências intelectuais europeias, já em 1870, o Manifesto Republicano chamara a atenção para a "excepcionalidade americana" do regime político que então vigorava no país (Bello, 1964; Bethell, 2010; Cervo e Bueno, 1992; Faoro, 1991; Holanda, 1985; Preuss, 2011; Ricupero, 2017; Silveira, 2003) ${ }^{2}$. No texto fundador do republicanismo brasileiro, depois da crítica ao poder moderador, que corresponde ao grosso do escrito, mas apenas repete argumentos já levantados por liberais, aparece um raciocínio novo na fórmula: "somos da América e queremos ser americanos" (Manifesto de 1870, 1890:59), isto é, a forma de governo adotada pelo país se chocaria com a orientação política do Continente. Nesse sentido, o Manifesto mescla a reivindicação de uma tradição brasileira de liberdade, expressa na Regência, com o anseio de pôr fim ao isolamento do país na América ${ }^{3}$. Tanto leva adiante a denúncia de liberais ao poder pessoal do imperador, que usurparia a soberania popular, como sugere que a monarquia seria causa de hostilidade com nossos vizinhos ${ }^{4}$. Significativamente, contudo, apesar da inovação, a crítica do Manifesto não ultrapassa certos limites, não chegando a tratar da escravidão. Tal posição permite a adesão ao Partido Republicano de fazendeiros escravistas depois do 13 de maio, apesar de um Luiz Gama e de um Silva Jardim não dissociarem a República da Abolição (Fernandes, 2006).

Exemplo dessa incipiente abertura para a América Latina é que um opúsculo como Ariel seja discutido no Brasil, mesmo que sua repercussão no país seja significativamente menor do que no restante da região ${ }^{5}$. Ainda que limitado, tal interesse pode ser tomado como sinal de que o Brasil, do final do século XIX, enfrenta ordem de problemas comparável ao resto da América Latina, em especial o novo desafio representado pela ascensão dos EUA como potência mundial ${ }^{6}$. Num sentido 
diferente, mas complementar, torna-se mais comum no período o que Ori Preuss (2011) chama de "encontros periféricos" entre membros das elites intelectuais e políticas brasileiras e hispano-americanas. Significativamente, essas relações se dão em bases mais igualitárias do que as que têm com europeus e mesmo com norte-americanos.

De maneira paralela, a consciência do contraste entre as duas partes do Novo Mundo é decisiva para a própria constituição da identidade latino-americana ${ }^{7}$. Assim, num momento de mudanças importantes, em que o Brasil deixa de ser um Império para se tornar uma República, membros das elites intelectual e política passam a se movimentar entre os dois polos americanos até para poderem entender quem são. No artigo examino como se entende, no início do novo regime, o lugar do Brasil na América; para tanto, trato, num primeiro momento, de autores monarquistas, como Eduardo Prado e Joaquim Nabuco, e, num segundo momento, de escritores mais próximos da República, como Rui Barbosa, Manoel de Oliveira Lima e José Veríssimo ${ }^{8}$.

A percepção de que o Brasil faz parte da América é estimulada principalmente pelo temor, cultivado por monarquistas como Prado e Nabuco, de que o país, ao buscar a prosperidade dos EUA, caia vítima da instabilidade e do autoritarismo que caracterizariam seus vizinhos hispano-americanos. Ironicamente, porém, esse medo indica que brasileiros não estão tão distantes de outros latino-americanos, ficando sugerido que o Império funcionava quase como uma barreira artificial contra tendências mais profundas. Autores mais identificados com o novo regime republicano, como Veríssimo, Rui Barbosa e Oliveira Lima, não deixam de compartilhar desses temores. O último, ao acentuar a suposta negatividade da herança racial e cultural latino-americana, chega até a sugerir que a ação do imperialismo norte-americano poderia ser até justificada. A consciência latino-americana não deixa, portanto, de ser titubeante, já que se percebe pertencer a um mundo que se rejeita. A reticência aparece no próprio uso do termo "América Latina" que é, entretanto, inusual até a proclamação da República9.

Em termos mais profundos, não se tem percebido que a questão principal por trás do debate brasileiro sobre a América do início da República é, na verdade, a da democratização. No entanto, o significado de democracia, mais do que institucional, é de transformação da sociedade, que vivia mudanças profundas como a Abolição, a imigração e a urbanização. Nessa referência, os EUA são identificados de maneira

DADOS - Revista de Ciências Sociais, Rio de Janeiro, vol. 61, nº 1, 2018 
direta com essas características, sendo entendidos, à la Tocqueville, como a expressão mais pura da democracia. A América Latina, por sua vez, é vista como região governada por caudilhos e habitada por índios, negros e mestiços. A República, portanto, como percebem, mesmo que a contragosto, os autores mais próximos dela, precisa enfrentar o problema do povo com o qual conta.

Será necessário um processo longo, contraditório, com avanços e recuos, para que, aos poucos, a antiga animosidade em relação aos hispânicos, herdada dos conflitos coloniais, ceda lugar ao reconhecimento da semelhança de condições, de estágio de desenvolvimento e de problemas a enfrentar. Ao mesmo tempo em que intelectuais brasileiros descobrem as afinidades que os vinculam aos hispânicos, outros sentem atração pela emergência do poder dos EUA. A elite intelectual e política brasileira se vê, assim, dividida entre dois diferentes modelos de republicanismo: o hispânico, com o qual o Brasil partilha semelhanças culturais, e de estágio de desenvolvimento político-econômico e o dos EUA, primeira república democrática dos tempos modernos, cujo imenso sucesso material e político se gostaria de imitar e reproduzir. De um lado, nosso passado e nosso presente, de outro, a imagem do que se gostaria fosse nosso futuro. Entre esses dois polos, ambos republicanos, se desenrolará um processo prolongado e complexo de tomada gradual de consciência do lugar do Brasil na América.

\section{A AMÉRICA COMO ILUSÃO E COMO PERIGO}

Enquanto no Império republicanos criticavam a "excepcionalidade americana" da forma de governo brasileira, com a proclamação da República defensores da monarquia passam a denunciar a quimera de se procurar imitar o exemplo dos demais países do Continente. O "vigoroso publicista nosso", ao qual Veríssimo faz alusão, Eduardo Prado, já em 1893, em A Ilusão Americana -impresso e recolhido pela polícia quando o país vivia a agitação da Revolta da Armada - denuncia a miragem de que seriam vítimas os republicanos ${ }^{10}$. Não é mero acaso que o livro apareça num momento em que o segundo governo republicano, de Floriano Peixoto, temia o possível reconhecimento por parte das potências europeias dos sublevados da Armada como beligerantes, além de perceber que seria decisiva a posição que os EUA assumiriam no conflito.

Quando o almirante Custódio Mello levanta a esquadra, em 6 de setembro de 1893, como já havia feito, com mais sucesso, dois anos antes 
contra o governo Deodoro da Fonseca, estavam estacionados na Baía da Guanabara um navio de guerra francês, três ingleses, um italiano e um português ${ }^{11}$. Os comandantes das embarcações decidem garantir a livre navegação na baía e proteger a vida e os bens de seus conacionais. Receosos de que suas ações pudessem ser interpretadas como quebra de neutralidade, os diplomatas das potências estrangeiras não aceitam, num primeiro momento, nem mesmo o convite do vice-presidente brasileiro para discutirem o conflito. Pouco depois, tomam a iniciativa de impedir o bombardeio da cidade do Rio de Janeiro alegando razões humanitárias; apenas o representante do governo alemão não concordava com a deliberação. Tal situação paralisa os revoltosos ao mesmo tempo que possibilita ao governo fortificar a capital federal.

Para resolver o impasse, a revolta ingressa em segunda etapa quando a frouxa liderança de Custódio cede lugar à enérgica intervenção do novo comandante do movimento, o contra-almirante Luís Felipe Saldanha da Gama, que tenta impor o bloqueio naval e busca juntar esforços com a Revolução Federalista, que estourara antes no Sul do país ${ }^{12}$. Simultaneamente, o encarregado de negócios brasileiro em Washington, o republicano histórico Salvador de Mendonça, empreende, com base na doutrina Monroe, uma verdadeira campanha nos EUA alertando para a possibilidade da vitória dos insurretos ${ }^{13}$. Consegue convencer o governo norte-americano do perigo de uma possível restauração monárquica e, com ela, da volta da influência europeia no Brasil, o que faz com que os EUA substituam o contra-almirante Oscar Stanton pelo também contra-almirante Andrew Benham como chefe das suas naves na Baía da Guanabara. O novo comandante se mostra disposto a bombardear as embarcações dos sublevados caso não permitam que navios mercantes de seu país atraquem no porto do Rio de Janeiro. Tal ameaça leva a um recuo dos rebeldes e ao rompimento do bloqueio. Contribui também para a derrota da Armada a proximidade da chegada da nova frota legalista que Salvador de Mendonça organizara nos EUA com auxílio do governo americano. Ainda mais importante, o firme apoio de São Paulo a Floriano impede que tropas federalistas vindas do Sul do país se juntem à esquadra sublevada. Em tal contexto, "jacobinos" desenvolvem uma forte campanha pela solidariedade continental, acusando os revoltosos de simpatias monarquistas ${ }^{14}$.

Contra tal argumento, Prado defende que a fraternidade americana seria uma mentira. Prova disso seria a conquista, pelos EUA, de quase metade do território mexicano e a não solidariedade do país com a 
Argentina e com Honduras, quando a Inglaterra se apoderou das ilhas Malvinas e do torrão de terra que foi batizado de Belize. Já durante a independência das ex-colônias ibéricas, Washington não teria prestado solidariedade aos revoltosos, só reconhecendo tardiamente as novas nações. Os norte-americanos, ademais, deixaram de participar do Congresso do Panamá convocado por Simón Bolívar. A república do Norte se apresentaria como protetora das demais nações americanas quando, na verdade, sua intenção seria impor o protetorato ao resto do Continente. Portanto, "seria um erro colossal acreditar que nos Estados Unidos há simpatias pela América do Sul, Brasil e especialmente pela forma de governo que lhe foi aplicada há quatro anos" (Prado, 1895:88). Em contraste, o monarquista recorda o apoio decisivo que as ex-colônias da Espanha e de Portugal receberam da Inglaterra no momento de sua emancipação política. Acima de tudo, se a necessidade maior da região consistia em capitais e braços, se poderia recorrer a Albion para os primeiros, o que não ocorreria com sua ex-colônia americana.

Não deixa de ser significativo que A Ilusão Americana mire especialmente os EUA, o que não ocorria com os artigos que Prado publicara anteriormente na Revista de Portugal sob o pseudônimo de Frederico S., e que foram editados já em 1890 em livro com o título de Os Fastos da Ditadura Militar no Brasil. Nele chegara a afirmar que

\footnotetext{
o Brasil de hoje pode chamar-se a si mesmo - Estados Unidos - tanto quanto quiser. Os únicos Estados Unidos que na História corresponderão sempre à ideia de liberdade, de dignidade e de força moral, são os Estados Unidos da América do Norte (Prado, 1902a:37).
}

Alertara então especialmente para como o pronunciamento militar que dera origem à República nos colocara na trilha das ditaduras e das revoluções, para não falar da ruína financeira, que marcariam as repúblicas hispano-americanas ${ }^{15}$. No livro de 1893, persiste a antipatia pelos vizinhos do Brasil, caracterizados como imersos num verdadeiro "rio de sangue, [...] um contínuo morticínio" (Prado, 1895:5). Para marcar a diferença do país lusófono, supostamente isolado das nações hispânicas, Prado chega a apelar para o mito da ilha Brasil, o país correspondendo a um território de dimensões continentais, separado dos vizinhos por dois grandes rios.

No entanto, Prado identifica no imperialismo norte-americano o principal perigo enfrentado pelos brasileiros. Interessaria especialmente 
ao país anglo-saxão novos mercados, garantidos por tratados comerciais preferenciais, já que, em igualdade de condições, a plutocracia que dominaria os EUA seria incapaz de competir com as manufaturas europeias. Essa seria a principal motivação por trás da Conferência Internacional dos Estados Americanos de Washington, de 1889. A recém-proclamada república brasileira teria sido "o primeiro país que cedeu aos Estados Unidos assinando o tratado de reciprocidade comercial" (Prado, 1895:84-85) ${ }^{16}$. Em termos doutrinários, antes mesmo de Theodore Roosevelt inaugurar a diplomacia do big stick, adverte para como o secretário de Estado William Evarts propusera um aditamento para a doutrina Monroe, no sentido de que a América deveria estar destinada aos "americanos, sim senhor, mas entendemo-nos, para os americanos do Norte" (ibidem:30). Nessa orientação, não seria de surpreender a incorporação aos EUA primeiro do México, depois da América Central e, finalmente, da América do Sul.

Num sentido mais profundo, A Ilusão Americana alerta especialmente para os resultados nefastos da imitação das instituições e da cultura norte-americanas. Dessa maneira, como aponta Skidmore (1975), inverte a crítica republicana de que o Império brasileiro copiaria a monarquia constitucional britânica. Já as ex-colônias da Espanha, ao adotarem, logo depois da independência, a forma de governo republicana, teriam se lançado "na longa, vã, tormentosa, sangrenta e já degradante e inútil tentativa, quase secular, de querer implantar na América Latina as instituições de uma raça estranha" (Prado, 1895:27-28) ${ }^{17}$. O Brasil incorreria, com um certo atraso, no mesmo erro, em 15 de novembro de 1889. No entanto, como já alertara Plínio:

o relógio que dava o tempo certo em Catânia errava em Roma. Assim as instituições podem dar certo nos seus países de origem e trazer a confusão nos países para onde arbitrariamente as transmudam (Prado, 1895:97).

No caso que interessa especialmente a Prado, o Brasil estaria separado dos EUA "não só pela grande distância, como pela raça, pela religião, pela índole, pela língua, pela história e pelas tradições de nosso povo" (ibidem:5).

Nessa orientação, apesar do seu pouco apreço pelas repúblicas hispanoamericanas, o monarquista brasileiro, ao defender a originalidade do seu país, antecipa o principal alerta arielista: o perigo de se apagar a diferença entre a América Latina e a América saxônica ${ }^{18}$. Mesmo que os 
autores não tenham consciência da semelhança, ela não é resultado de mero acaso. Além de perceber o desafio já representado pelos EUA, suas fontes intelectuais são as mesmas: a moderna ciência social europeia já tendo demonstrado, segundo o autor, que "as sociedades devem ser regidas por leis saídas da sua raça, da sua história, do seu caráter, do seu desenvolvimento natural" (Prado, 1895:27). Nesse sentido, avalia que a prosperidade dos EUAé produto da fertilidade de seu solo e, principalmente, das qualidades da raça anglo-saxã, não tendo nenhuma relação com a forma de governo. Mesmo assim, como Paul Groussac, Rúben Darío e o autor de Ariel, considera que a cultura norte-americana ficaria muito aquém das realizações materiais do país, avaliando até que em "muitos respeitos os Estados Unidos são ainda uma colônia. A civilização vem-lhe da Europa" (ibidem:66) ${ }^{19}$.

Diante da Guerra Hispano-Americana, em artigo para a Revista Moderna, publicação editada em Paris, Prado contrasta, como os arielistas, os EUA e a Espanha. No entanto, não vai ao ponto de afirmar a identidade ibérica do Brasil. A raça espanhola seria marcada pela grandeza, dignidade e fidalguia, que a faria bater-se com heroísmo, mesmo que sem esperanças. Qualidades como essas seriam incompreensíveis para o "mercantilismo prático de americanos" (Prado, 1898:599)20. De maneira significativa, o autor, assim como outros latino-americanos antes e depois dele, acredita que as diferenças entre as duas partes da América aparecem especialmente nas relações raciais: "hoje, em Cuba, sob o tão vilipendiado jugo espanhol, não há ódios de raça" (ibidem:598). Já nos EUA, apesar de a Guerra Civil ter concedido a liberdade e direitos políticos aos negros, eles continuariam a ser tratados com desprezo pelos brancos.

Na verdade, os anglo-saxões, dos dois lados do Atlântico acreditariam, como McKinley, que uma nação teria o direito de intervir em outra quando seus interesses comerciais fossem afetados por má administração. Ou, em termos ainda mais fortes, defenderiam, como Lord Salisbury, que nações fracas e malgovernadas não teriam direito de existir. Ainda, identificariam, como Sir John Lubbock, a América do Sul com a waste continent, um continente desperdiçado ${ }^{21}$. Em outras palavras, demonstrariam verdadeiro desprezo pelo direito internacional. Portanto, os rebeldes cubanos não passariam de "instrumentos inconscientes da política dos sindicatos senatoriais e açucareiros dos Estados Unidos que especulam sobre o sangue e o heroísmo de patriotas" (Prado, 1898:598). 
O destino do Texas, primeiro rebelado contra o México e em seguida absorvido pelos EUA, deveria logo se repetir com Cuba.

A questão social, que se acreditara ser um problema inexistente nos EUA, revelara ser uma ameaça ainda mais séria no país do que no Velho Mundo, estando prestes a explodir. De forma não muito coerente com suas considerações a respeito da riqueza norte-americana, Prado relaciona a maneira de tratar a questão com a forma de governo adotada. Na república, em que tudo seria transitório, os governantes, também eles provisórios, não teriam interesse em melhorar a condição operária, já que não tirariam benefício de tal iniciativa. Os monarcas, em contraste, teriam consciência de que uma catástrofe social poderia levar ao fim de suas respectivas dinastias. Não por acaso, segundo $A$ Ilusão Americana, todas as reformas sociais teriam sido iniciativas de monarquias. De maneira curiosa, contrasta até a forma pela qual se pôs fim à escravidão no Brasil com a dos EUA. Apesar de ter sido o último país independente do hemisfério ocidental a abolir a instituição servil, a monarquia latina teria feito isso de forma pacífica, em contraste com a violência, que produziu até uma guerra civil, da república saxã ${ }^{22}$.

É igualmente a República e, em especial, a agitação dos primeiros anos do novo regime que estimula o interesse de Joaquim Nabuco pelo Continente americano. Em carta ao barão do Rio Branco, em julho de 1890, o antigo abolicionista já sugere possíveis resultados da aproximação do Brasil com o resto da América:

entramos na série dos governos pessoais militares e daí virá a degradação do exército, a bancarrota pela ladroeira e pela especulação, como nas demais repúblicas do mesmo tipo, o governo no 'Estado' de verdadeiros caudilhos, cercados de uma quadrilha de analfabetos, e por fim o desmembramento se o sentimento nacional não reagir à última hora" (Nabuco, 1949:188) ${ }^{23}$.

Publica, já no governo Prudente de Morais, quando são restabelecidas as garantias constitucionais e busca-se, por meio de uma anistia parcial, a pacificação com os federalistas, uma série de artigos, entre janeiro e março de 1895, no Jornal do Commercio, que parte e contesta o livro do chileno Julio Bañados Espinosa, Balmaceda, su Gobierno y la Revolución de 1891, saído no ano anterior em Paris.

O escritor brasileiro procura tratar de questões que acredita dizerem respeito a toda a América Latina, inclusive ao seu país. Nesse sentido,

DADOS - Revista de Ciências Sociais, Rio de Janeiro, vol. 61, nº 1, 2018 
volta a indicar: "o interesse que antes já me inspiravam as coisas sul-americanas aumentou naturalmente depois da Revolução de 15 de novembro. Desde então começamos a fazer parte de um sistema mais amplo" (Nabuco, 1895a:211) ${ }^{24}$. No Prefácio do livro logo publicado como Balmaceda, chega a argumentar que nas universidades sul-americanas seria útil criar uma cadeira de Revolução Comparada, possível complemento do já estabelecido Direito Constitucional. É verdade que no mesmo Prefácio se defende de ter escrito "a pretexto e acoberto do incidente chileno", sobre "os fatos, os personagens, e as teorias da Ditadura a que estivemos sujeitos". Nesse sentido, ressalta que as diferenças entre os dois países "têm muito maior importância do que as semelhanças" (Nabuco, 1895a:IV).

Só no Posfácio, sugestivamente intitulado “A Questão da América Latina", confessa:

“não dei no Jornal do Commercio todos os motivos que me sugeriram este estudo sobre Balmaceda. Posso agora completar meu pensamento. Sempre que antes e depois do 15 de novembro algum partidário do regime monárquico pretendia que entre nós a república dificilmente seria um governo responsável por não termos a têmpera dos países que modelam os seus governos à sua feição, a resposta era: 'E o Chile?'” (Nabuco, 1895a:207).

De acordo com este autor, apesar de ser uma república, o Chile possuía a mesma estabilidade e liberdade do Império brasileiro, o que se deveria ao fato de que os dois países haviam tido um governo parlamen$\operatorname{tar}^{25}$. Nessa referência, alguém teria dito que "só encontrei duas nações organizadas e livres na América Latina, o Império do Chile e a República do Brasil" (Nabuco, 1895a:3). Ainda em termos invertidos, segundo o autor, se a república chilena corresponderia a uma aristocracia, a monarquia brasileira seria "a sociedade sem exceção alguma a mais igualitária do mundo" (ibidem:4) ${ }^{26}$.

O conflito no Chile entre o Poder Executivo e o Poder Legislativo se iniciara na Presidência anterior, de Domingo Santa María. O então primeiro mandatário adotara, contra a Igreja Católica, responsável pelos casamentos, registros de nascimento, registros de morte e os cemitérios do país andino, um programa de laicização que abriu caminho para uma verdadeira "guerra religiosa". Por sua vez, Balmaceda, que tinha sido ministro do Interior de Santa María, se esforça, ao tornar-se presidente, por levar a cabo um ambicioso programa de moderniza- 
ção, ao mesmo tempo que tenta reunificar a "família liberal". Com o tempo, quase todos os setores políticos chilenos voltam-se contra o reformador. Nesse ambiente, o Congresso não aprova o orçamento para 1891, o conflito entre Executivo e Legislativo logo se transformando numa guerra civil. Exército e Marinha tomam posições opostas no conflito, o primeiro se alinhando ao presidente e a segunda ao Congresso. Finalmente, derrotado, Balmaceda asila-se na embaixada argentina. Em 19 de setembro, simbolicamente um dia depois do que seria o fim de seu mandato presidencial, suicida-se. Morrem na guerra civil cerca de seis mil pessoas (Collier e Sater, 1996).

Segundo Nabuco, o presidente deposto procurara substituir o governo parlamentar, que teria se formado ao longo do século XIX, pelo presidencialismo, o "sistema norte-americano, nunca ensaiado com sucesso em povo latino" (Nabuco, 1895a:168-169). Em sentido contrário, a grandeza do Chile derivaria diretamente do sistema de governo que desenvolvera com o tempo.

Em termos mais profundos, a disputa entre a presidência e o parlamento expressaria o choque entre o princípio de inovação e o princípio de conservação. Nessa referência, como indica José Almino de Alencar (2008; 2009), o autor de Balmaceda contrasta a continuidade reformista conservadora com a mudança revolucionária jacobina. Na melhor tradição conservadora, identifica a segunda com uma postura abstrata, que chama de "política silogística": "uma pura arte de construção no vácuo. A base são teses e não fatos; o material, ideias e não homens; a situação, o mundo, e não o país; os habitantes, as gerações futuras, e não as atuais" (Nabuco, 1895a:16-17). Em sentido oposto, não só na Inglaterra a Constituição não seria escrita, ela correspondendo, de maneira geral, aos costumes de um povo. Portanto, como já havia notado o fundador do moderno conservadorismo: "há uma sorte de presunção contra a novidade, tirada da observação profunda da natureza humana e dos negócios humanos" (Burke apud. Nabuco, 1895a:183-184; ênfases no original) ${ }^{27}$.

Nabuco sugere, entretanto, que Bañados Espinosa tenta pintar Balmaceda como um continuador de Diego Portales e Manuel Montt, os grandes nomes da política conservadora chilena do século XIX, que, de fato, favoreceram uma Presidência forte. Defende, em sentido inverso, que o presidente deposto teria se chocado com a linha evolutiva de seu país:

DADOS - Revista de Ciências Sociais, Rio de Janeiro, vol. 61, nº 1, 2018 
Bernardo Ricupero

Balmaceda irrompe na história chilena como uma aparição imprevista; é uma evocação, pode-se dizer, na presidência do Chile, do gênio sul-americano da ditadura que nunca havia penetrado nela" (Nabuco, 1895a:14).

Mais uma vez, de maneira similar à caracterização de Burke da Revolução Francesa, considera que o renovador se assemelharia a um verdadeiro invasor, que procuraria apagar os melhores traços da tradição nacional. Antes, a república chilena e a monarquia brasileira se destacariam numa região caótica pela ordem que conseguiram imprimir a seus povos. É verdade, porém, que, em sentido contrastante, o escritor brasileiro também argumenta que o presidencialismo à americana casaria mal com o gênio latino.

Segundo Nabuco, em razão de romper com a história chilena, o presidente reunira contra si o melhor do país: "os antigos partidos, os homens de reputação formada com raras exceções, a mocidade, a sociedade, a mulher, a Igreja" (Nabuco, 1895a:193). Isto é, numa linguagem mais direta: "a boa sociedade formava quase um só partido" (ibidem:100). Ou, em termos ainda mais sintéticos: "a 'antiga sociedade' rompera com Balmaceda". De maneira complementar, o partido balmacedista seria composto por "elementos desconhecidos, anônimos, democráticos" (ibidem:117). Especialmente assustador para o autor é perceber que o presidente defenderia "a guerra social pregada em linguagem propositalmente vulgar. A riqueza é considerada inimiga da nova democracia Balmacedista" (ibidem:108). Ou, de maneira mais direta, no Chile, como no Brasil: "o método radical é mandar abrir as portas para que todos entrem, como a República fez a 15 de novembro" (ibidem:191).

No entanto, o povo teria, de início, se mostrado indiferente à pregação. Com o tempo, reagira mesmo com hostilidade à tentativa de profanar a propriedade, a Igreja, as posições consolidadas. Nabuco avalia que tal reação seria indício de que o poder da chamada oligarquia chilena teria bases profundas, sustentando-se no próprio povo. Nesse sentido, considera que tal oligarquia, baseada na grande propriedade fundiária, seria, na verdade, uma aristocracia, assemelhando-se à que existiria na Inglaterra. Em termos políticos, "o que se chama a 'oligarquia chilena' é apenas a tradição de governo transmitida de uma a outra geração", com o cuidado de "que não entre indistintamente toda a gente" (ibidem:190). O povo, por sua vez, corresponderia quase aos sonhos 
aristocráticos do autor, já que "não estava minado pela inveja, estava longe da teoria, não conhecia o ressentimento que torna simpáticas as ideias de cunho socialista" (ibidem:117).

Conclui daí que as bases da democracia no Brasil seriam ainda mais frágeis do que no Chile. Ganha sentido, dessa forma, a advertência do Prefácio de Balmaceda de que as diferenças entre os dois países seriam mais significativas do que suas eventuais semelhanças. No caso da república chilena, a sociedade conseguiria conter o governo, ao passo que no Brasil, "se tivemos a liberdade na monarquia foi só porque o poder se continha a si mesmo" (ibidem:208). Em outras palavras, o Chile seria mais uma exceção na América Latina do que o próprio Brasil. O resultado da revolução chilena de 1891, assim como a Guerra Civil dos EUA, demonstraria a solidez das instituições dos dois países, que os tornariam exceção num continente marcado pela instabilidade e pela turbulência. No caso de seu país, Nabuco imagina uma situação até pior do que a de seus vizinhos:

se a ditadura assumisse o tipo sul-americano, a sociedade brasileira criada na paz e na moleza da escravidão doméstica e da liberdade monárquica [...] faria renúncia da sua liberdade, dos seus interesses, das suas propriedades" (ibidem:209).

Num sentido amplo, Balmaceda sugere que o desgoverno sul-americano fatalmente faria com que o resto do mundo se interessasse pela região, como teria ocorrido com a "desaproveitada" África no Congresso de Berlim. No entanto, descarta, sem grande explicação, a possibilidade do protetorado europeu, apesar de imaginar que a já iniciada imigração maciça do Velho Mundo poderia ter um efeito comparável ao de uma verdadeira colonização. A outra alternativa, a do monroísmo, também não seria factível. Em termos extremos, os EUA não aceitariam absorver povos com índole muito diferente da sua; em termos mais modestos, não teriam interesse em estabelecer uma zona de influência, já que ela abriria caminho para uma desenfreada especulação, como teria ocorrido no Sul do país depois da Guerra Civil. Ou seja, na verdade, o resto do mundo, ao contrário do que o autor afirmara pouco antes, não teria grande interesse pela América Latina. Portanto, Nabuco considera que a "solução do problema tem [...] que ser procurada dentro mesmo de cada um de nossos países" (ibidem:216). Neles identifica, esperançosamente, a presença de "homens cuja cultura rivaliza com a mais brilhante cultura europeia", isto é, gente não muito 
diferente do próprio escritor de Balmaceda e possivelmente capazes de formar uma Liga Liberal do Continente.

Num sentido mais concreto, a solução elitista imaginada por Nabuco é generalizar para os vizinhos os instrumentos que permitiriam a autonomia do sistema político brasileiro: "o que a América do Sul precisa é um extenso Poder Moderador, um Poder que exerça a função arbitral entre partidos intransigentes" (ibidem:205). Em outras palavras, em acordo com a tradição saquarema, acredita, como indica Christian Lynch (2012), que uma sociedade invertebrada deve ser corrigida pela ação de um Estado ilustrado. Na verdade, o autor de $O$ Abolicionismo, como aponta Marco Aurélio Nogueira (2010), oscila ao tratar do poder pessoal. Antes da República, havia sido um crítico da ingerência do Imperador na política, mas significativamente visara especialmente a sua vacilação em utilizar as prerrogativas que possuía para fazer avançar a causa da emancipação. Depois do 15 de novembro, em Um Estadista do Império, Dom Pedro II passa a ser retratado como uma espécie de protetor das minorias e da oposição.

O republicano desiludido Veríssimo percebe, porém, a inconsistência do elogio de Nabuco ao Segundo Reinado: "se a liberdade brasileira foi uma dádiva generosa do monarca e da monarquia e não uma conquista de nossa civilização, o elogio, lisonjeiro talvez para o homem, transforma-se vitupério para o estadista" (Veríssimo, 1895). Em outras palavras, o autor de Balmaceda defenderia uma solução artificial para os problemas do seu país e continente, incapaz de realmente transformá-los. Prova disso seria a própria anarquia dos primeiros anos da República brasileira, já que numa sociedade com bases mais sólidas, "o eclipse da liberdade que assistimos não seria tão demorado" (Veríssimo, 1895:116) ${ }^{28}$.

No livro "irmão" de Balmaceda, A Intervenção Estrangeira durante o Levante de 1893, fica ainda mais claro como Nabuco, ao escrever sobre o Chile, pensa no Brasil ${ }^{29}$. O livro, também publicado em 1895, é igualmente produto de artigos antes aparecidos no Jornal do Commercio, só que a respeito da Revolta da Armada. A dedicatória a Augusto de Castilho, comandante da fragata portuguesa Mindelo, que ofereceu asilo aos sublevados, é indicação inequívoca das simpatias do autor. A tese principal do livro é bastante simples: "o procedimento das potências intervindo, alterou completamente o equilíbrio das forças" (Nabuco, 1895b:113) em favor do governo Floriano. 
Na verdade, a inspiração de Nabuco para tratar da recente história chilena provavelmente veio da percepção de que o inédito sucesso do levantamento da esquadra daquele país, em 1891, contra o presidente Balmaceda contribuiu, como indica Sérgio Correa da Costa (1979), para a revolta, dois anos depois, da armada brasileira contra o "marechal de ferro". No entanto, diferentemente do primeiro caso, em que os revoltosos, tendo se estabelecido em Iquique, no norte do Chile, região rica em salitre recém-conquistada do Peru, reuniram um poderoso exército, os sublevados brasileiros ficaram paralisados na Baía da Guanabara devido à ação da esquadra estrangeira e à expectativa de como evoluiria a Revolução Federalista no sul do país. Reforçando a analogia, Nabuco lembra que também os revoltosos chilenos nunca foram reconhecidos como beligerantes, o que, diferentemente do que ocorreu no Brasil, não teria impedido que bloqueassem portos de seu país. Igualmente de maneira similar ao ditador do país andino, o ditador brasileiro procuraria garantir o apoio do exército aumentando-lhe seu soldo. Além de tudo, o governo de Floriano teria recorrido aos préstimos de oficiais balmacedistas. Mais importante, como no Chile, o recente período "jacobino" se colocaria contra o melhor do país, por meio do "regime da Casa de Coerção imposto a homens de caráter ilibado, ao que a sociedade do Rio de Janeiro possuía de melhor" (Nabuco, 1895b:120) ${ }^{30}$. Portanto, Floriano não mereceria tanto o epíteto de jacobino, normalmente atribuído ao general alagoano, já que, na verdade, "diferente de tudo que até então se tinha visto em nossa raça", que por isso mesmo se impressionara profundamente, teria "a fibra ordinária dos antigos caudilhos do Prata" (ibidem:128).

Mas, se era verdade que o Brasil republicano se assemelhava cada vez mais a seus vizinhos hispano-americanos, teria sido somente devido ao apoio norte-americano que as forças florianistas teriam conseguido suplantar a Revolta da Armada. Mais do que a intervenção estrangeira, que criaria uma situação de desequilíbrio entre governistas e sublevados, teria sido a mudança de posição dos EUA, desde a chegada do contra-almirante Benham, que decidiu a contenda em favor da república brasileira. Em outras palavras, Nabuco prefere explicar a derrota da Armada pela ação das potências estrangeiras, especialmente os EUA, não dando atenção ao peso do apoio de São Paulo a Floriano, o que abre inclusive caminho para que o marechal aceite ser sucedido por um civil paulista.

A mudança norte-americana seria, por sua vez, fruto de uma campanha promovida pelo governo brasileiro que, usando o exemplo do pre-

DADOS - Revista de Ciências Sociais, Rio de Janeiro, vol. 61, nº 1, 2018 
cedente do príncipe austríaco Maximiliano, que se tornara imperador do México com apoio de forças francesas, sugeriria, contra o monroísmo, que "a Europa maquinava uma intervenção no Brasil para restabelecer a monarquia" (ibidem:124). A partir daí, o governo brasileiro se mostraria disposto a aceitar, na prática, o protetorado norte-americano, sendo supostamente prova disso a atitude subserviente do Senado, que aprovara um projeto para se cunhar duas moedas, uma com a efígie de Cleveland para ser oferecida a Floriano e outra com a efígie do presidente do Brasil para ser oferecida ao presidente dos EUA ${ }^{31}$.

Há muitos pontos de contato entre a crítica à República de Eduardo Prado e a de Joaquim Nabuco: ambos a criticam numa referência americana mais ampla, destacando como o exemplo norte-americano seria uma miragem, o mais provável sendo que o Brasil caísse na anarquia e na instabilidade de seus vizinhos hispano-americanos. Essas convergências não são mero acaso, já que os dois autores estiveram envolvidos, em maior ou menor grau, com o movimento monarquista ${ }^{32}$. Nessa referência, chegam a temer, em algum momento, a possibilidade de o Brasil se tornar um protetorado dos EUA. É verdade, porém, que A Ilusão Americana chama a atenção especialmente para o primeiro ponto, destacando a ação do imperialismo norte-americano e as diferenças culturais entre o Brasil e os EUA. Por sua vez, Balmaceda e A Intervenção Estrangeira durante o Levante de 1893 se interessam particularmente pela tendência do Brasil de passar a se assemelhar, com a proclamação da República, ao resto da América do Sul, ressaltando especialmente os aspectos institucionais dessa aproximação.

O projeto de restauração monárquica não tem, entretanto, sucesso, resultado para o qual contribui a própria indiferença da família imperial e a descrença generalizada, mesmo antes de 1889, quanto à real possibilidade de um Terceiro Reinado. Passadas as duas primeiras presidências militares, o governo Prudente de Morais continua a ser um período de agitação, marcado pelo final da Rebelião Federalista, as escaramuças entre "jacobinos" e monarquistas e o desencadeamento da Revolta de Canudos. No entanto, a partir daí, se assentam as bases para o arranjo oligárquico, consolidado na presidência Campos Salles.

Com a estabilização da Primeira República, não há mais espaço para a pregação monarquista. Mas antes, políticos e intelectuais como Eduardo Prado e Joaquim Nabuco, realizam, nas palavras de Maria de Lourdes Janotti, "o conjunto mais significativo de críticas e denúncias 
sobre os primeiros anos da República" (Janotti, 1986:84). Voltam-se, porém, apenas para os integrantes de seu círculo social, não dando grande importância para a possibilidade de um monarquismo popular, cuja existência logo se pôde constatar no sertão da Bahia.

Apesar da derrota monarquista, a interpretação da proclamação da República elaborada pelos vencidos foi muito além do grupo, repercutindo na historiografia e, a partir dela, na visão mais ampla a respeito do fim do Império ${ }^{33}$. Nessa referência, o 15 de novembro não passaria de um golpe militar assistido com indiferença pela população e alimentado pela insatisfação dos grandes proprietários rurais com a Abolição. Desde então, passaria a imperar a instabilidade e a ditadura militar, se não o simples domínio oligárquico. De forma contrastante, o Segundo Reinado seria marcado pela paz, tendo garantido a unidade nacional.

Além disso e de maneira pouco óbvia, a visão monarquista a respeito da República contribuiu para entender o Brasil como parte da América. Se, antes, o Império ia procurar suas referências intelectuais na Europa e contrastava sua suposta paz e estabilidade com a violência e anarquia das repúblicas hispano-americanas, com o 15 de novembro o país busca inspiração nos seus vizinhos, seus problemas também passando a ser interpretados como comparáveis aos do resto do Continen$t^{34}$. Nesse sentido, a aproximação institucional que a República promove do Brasil com a América não deixa de contribuir igualmente para o desenvolvimento de uma certa identidade cultural, que contrasta repúblicas latinas com a república saxã. Não deixa de ser significativo, entretanto, que essa aproximação identitária com a América do Sul e a América Latina - termos que são então usados quase indiscriminadamente - seja, em grande parte, negativa, promovida, não por acaso, por monarquistas críticos ao novo regime (Baggio, 1998; Preuss, 2011; Silveira, 2003).

\section{A AMÉRICA COMO REALIDADE E POSSIBILIDADE}

Muitas das considerações de Rui Barbosa sobre a América Latina e os EUA não são muito diferentes das de Prado e de Nabuco ${ }^{35}$. Da mesma forma que sucedera com os monarquistas, os agitados primeiros anos da República, em especial o governo Floriano Peixoto, estimularam o antigo vice-chefe do governo provisório a associar o Brasil às "pobres repúblicas da América latina" (Barbosa, 1896:236). Mais diretamente, Cartas de Inglaterra, compilação de artigos publicados em 1895 no Jornal

DADOS - Revista de Ciências Sociais, Rio de Janeiro, vol. 61, nº 1, 2018 
do Commercio, em que uma "carta" ironicamente intitulada "Duas glórias da América" tratara especificamente do argentino Juan Manuel de Rosas e do paraguaio Doctor Francia, é resultado do exílio londrino motivado, por sua vez, pela Revolta da Armada ${ }^{36}$.

Como já haviam feito outros autores, Rui Barbosa vincula o caudilhismo ao despotismo ${ }^{37}$. Refletindo a dificuldade de explicar como funciona um certo estilo de política que aparece na América Latina, e aparentemente não tem precedentes - o que continua a intrigar analistas de fenômenos posteriores, como o "populismo" - se procura aproximá-lo de exemplos mais conhecidos para o pensamento Ocidental. Por exemplo, o papel que o júri teria na Inglaterra, o município na Suíça, a justiça federal nos EUA, seria desempenhado pela lei marcial nessa parte esquecida do mundo. Num contexto em que imperaria a violência, a importância dos caudilhos particulares é até relativizada: "Francia e Rosas são apenas duas encarnações figurais, análogas a outras, de um estado social generalizado, renascente, talvez orgânico na América latina" (ibidem:332). Além de tudo, com referências óbvias para seus leitores brasileiros de então, sugere que os caudilhos procurariam amparar seu arbítrio no americanismo.

Também como Prado e Nabuco, Rui não demonstra maior simpatia pelos EUA, avaliando até que "socialmente não há nação mais agitada pelo espírito de ódio e revolta" (ibidem:345). Prova disso seriam, como já indicara A Ilusão Americana, as relações raciais e de classe que prevaleceriam no país. Nessa orientação, o principal autor da Constituição republicana brasileira, que buscara inspiração na Constituição norteamericana, sugere que "a Constituição americana vem a ser apenas uma variante da Constituição inglesa" (ibidem:211-212).

Mas apesar de todas as coincidências com os monarquistas, Rui faz questão de se diferenciar deles. Respondendo a Afonso Celso, admite que no Império haveria mais liberdade do que na República; no entanto, não atribui o problema à forma de governo - questão pela qual esclarece não nutrir preferências abstratas -, mas ao militarismo, associado ao florianismo. Portanto, avalia, em termos mais profundos, que até em razão da impossibilidade da restauração monárquica, seria necessário lutar na República pela restauração da liberdade. Nesse sentido, semelhanças entre as Cartas de Inglaterra, A Ilusão Americana, Balmaceda e A Intervenção Estrangeira durante o Levante de 1893 são indicação de como os primeiros anos da República ajudam a formar, entre setores 
da elite intelectual e política, apesar de todas as suas diferenças, um certo consenso a respeito da necessidade de se evitar tanto a anarquia latino-americana como a descontrolada democracia norte-americana, supostos riscos que o Brasil passara a enfrentar desde 1889.

Significativamente, se prevalece ainda a instabilidade na maior parte da presidência de Prudente de Morais, tal situação começa a se modificar no final de seu governo. Mais especificamente, quando o presidente retorna, em março de 1897, ao Rio de Janeiro, depois de se licenciar por motivos de saúde, imprime nova orientação à administração. Reprime a revolta "jacobina" da Escola Militar do Rio de Janeiro e, a partir daí, consegue neutralizar o até então todo-poderoso Partido Republicano Federal (PRF) e seu líder, Francisco Glicério. Com o fracasso do atentado de 5 de novembro contra Prudente, que custa a vida de seu ministro da Guerra, marechal Machado Bittencourt, o governo toma definitivamente as rédeas da situação. Em meio à comoção geral, decreta estado de sítio e controla a oposição (Bello, 1964; Carone, 1981). Assenta-se, desde então, as bases da república oligárquica que, de forma sugestiva, como nota Renato Lessa (1988), não se volta preferencialmente contra a ordem imperial, mas contra os agitados primeiros anos do novo regime.

De maneira mais direta do que Rui Barbosa, Manoel de Oliveira Lima se contrapõe a Eduardo Prado e a Joaquim Nabuco. No entanto, nega, como o jurista baiano, a possibilidade de uma restauração monárquica. Nesse sentido, avalia que, diferente do que sugeria a propaganda "jacobina", os monarquistas seriam muito fracos, como provaria a incapacidade deles de se organizarem em partido digno do nome ${ }^{38}$. Mesmo assim, não deixa de contestar os dois monarquistas em Sept Ans de République au Brésil, livro saído na França em que são reeditados dois trabalhos anteriormente aparecidos na Nouvelle Revue, e numa série de artigos publicados, entre 1896 e 1898 na Revista Brazileira e no Jornal do Commercio, depois reunidos em Nos Estados Unidos ${ }^{39}$. Em termos mais fortes, refuta os argumentos de seus antagonistas; tanto contesta que a República lançaria o Brasil na mesma instabilidade de seus vizinhos hispano-americanos, como defende que "à ilusão americana é conveniente contrapor a realidade americana" (Lima, 1899:45; ênfase no original).

Como admitira Nabuco, teria sido o Exército que, depois do 15 de novembro, garantiria a manutenção da unidade brasileira como que ocu-

DADOS - Revista de Ciências Sociais, Rio de Janeiro, vol. 61, nº 1, 2018 
pando o lugar que antes fora da Coroa. Com a consolidação do federalismo e a subsequente prosperidade material de alguns estados, já não haveria motivos para a desagregação territorial. Paradoxalmente, Floriano, tomado por outros como exemplo de caudilho do tipo platino, é elogiado "por ter sido, o primeiro, na América latina, a esmagar uma revolução militar" (Lima, 1896:34). É verdade que Oliveira Lima escreve quando já se tem no horizonte a subordinação do poder militar ao poder civil, o que é vislumbrado desde a posse de Prudente de Morais na Presidência. Imagina, assim, que depois de "quase quatro anos de desordem e de conflitos e de choques violentos das duas classes armadas" (ibidem:26), o presidente civil possa garantir condições para as futuras paz, tranquilidade e prosperidade.

Na verdade, o historiador sugere que, no contexto do Continente, a estabilidade do Segundo Reinado seria mais a exceção do que a regra: "o Brasil por sua organização em monarquia hereditária e pelo caráter mais tranquilo de seus filhos gozou, só, em plena América do Sul, dos benefícios de quarenta anos de paz interior" (ibidem: 4$)^{40}$. Nessa referência, a América Latina mereceria a caracterização do venezuelano César Zumeta como um "continente doente" ${ }^{41}$.

A própria estabilidade monárquica do Brasil seria apenas aparente, já que o "trono não se enraizou no solo republicano da América" (ibidem:7). Num sentido mais imediato, a Abolição teria levado os fazendeiros a se afastarem do Império, ao mesmo tempo que o Positivismo e a propaganda republicana avançavam no Exército e nas escolas superiores. Num sentido mais profundo, o federalismo refletiria tendências consolidadas no país. Em resumo, "a República foi o resultado lógico da decomposição do regime monárquico e o retorno de uma tradição vivaz" (ibidem:14), estimulada, além de tudo, pela propagação de ideias estrangeiras.

Já em Nos Estados Unidos, Oliveira Lima se posiciona claramente em relação ao confronto entre os admiradores do país, que dele tudo desejariam copiar, e seus detratores, que o viam como responsável por todos os nossos males: "à parte os exageros do fanatismo, a verdade está incomparavelmente mais com os primeiros" (Lima, 1899:1). No entanto, em termos mais ambíguos, o jovem diplomata, que servira três anos em Washington sob Salvador de Mendonça, compartilha com seus contemporâneos um misto de atração e horror pelos EUA. Nessa orientação, chega a concordar com a caracterização, de Groussac, da repú- 
blica anglo-saxã como um mamute, enorme ser "disforme, ou melhor, [...] informe" (Lima, 1899:404) ${ }^{42}$. Como Prado e outros latino-americanos, sustenta que o país, em que tudo seria colossal e que teria atingido níveis inéditos de desenvolvimento material, não possuiria "uma grande literatura nem uma grande arte" (ibidem:405). Em suma, em termos culturais, não seria original, consumindo ainda a produção literária e artística do Velho Mundo. Agravando esta tendência, a vitória do Norte na Guerra Civil americana teria acentuado o utilitarismo característico do país.

Por outro lado, assim como os arielistas, avalia que os EUA seriam, sobretudo, o país da democracia: "o terreno da mais vasta e com todos os senões da mais genuína experiência democrática que o mundo tem presenciado" (ibidem:229). Como indicara Tocqueville, a igualdade se refletiria em todos os aspectos da vida norte-americana, do formato das casas ao conteúdo dos jornais, repercutindo especialmente na opinião pública, unanimemente medíocre ${ }^{43}$. Significativamente, em nenhuma outra sociedade a mulher teria igual influência. Em termos políticos, os norte-americanos teriam consciência de que possuiriam tanto direitos como deveres, o que abriria caminho para um acordo tácito entre governantes e governados e faria com que o sistema representativo de fato funcionasse. Não haveria, assim, espaço na democracia americana para o cesarismo. Segundo o historiador, todos esses fatores fariam dos EUA o país mais apto para resolver o "grande problema das relações entre o capital e o trabalho, que é o enigma do futuro" (Lima, 1899:513).

No entanto, a democracia americana enfrentaria um enorme desafio representado pela grande população negra do país. Além de tudo, Oliveira Lima admite que o Brasil, ao menos nas classes inferiores - na verdade, a grande maioria da população - seria um povo de mestiços, o que tornaria "especialmente interessante para nós o problema do futuro social dos africanos e seus descendentes" (ibidem:19). Considerações como as do diplomata pernambucano indicam como, no final do século XIX, a categoria de raça passa, por influência das doutrinas da época, a constituir uma forma pela qual a elite intelectual e política latino-americana, pretensamente branca, interpela seu outro, a "multidão", o "povo", mestiço, indígena e negro. A referência à raça possibilita, além do mais, naturalizar as diferenças sociais e, a partir daí, como apontam Waldo Ansaldi e Patricia Funes (1994) classificá-las e hierarquizá-las. O pernambucano ressalta que a questão negra seria espe-

DADOS - Revista de Ciências Sociais, Rio de Janeiro, vol. 61, nº 1, 2018 
cialmente importante no Norte do Brasil, região que não recebera grande número de imigrantes e, supostamente, em função disso, viveria uma situação de decadência e miséria ${ }^{44}$. Este quadro seria comparável, em grande parte, ao do Sul dos EUA, cujos estados também possuiriam um grande contingente de população de origem africana e passariam igualmente por um acentuado declínio.

Em que pesem as semelhanças entre os dois países, a situação do negro nos EUA seria, como defendera mais uma vez Prado e tantos outros latino-americanos, "infinitamente pior do que no Brasil, mercê da superior predisposição ao afeto da raça latina e do seu menor desprezo pelas raças inferiores" (Lima, 1899:21). Antes que seu protegido Gilberto Freyre defendesse a tese de que os brasileiros estariam mais próximos do ideal da democracia social do que os norte-americanos, Oliveira Lima argumenta que "nós estamos por consequente mais perto de pôr em prática a equidade social educando a raça negra" (ibidem:45). É verdade, porém, que o historiador é bastante ambíguo ao tratar das relações raciais, notando também que a mestiçagem ameaçaria "afundar-se num alastramento de raças inferiores" (ibidem:53).

Na verdade, Oliveira Lima não rompe com os preconceitos de sua época. Num tom supostamente condescendente, considera que o descendente do africano, desde que dirigido pelo descendente do europeu, ofereceria "qualidades preciosas pela sua obediência e rija musculatura" (ibidem:29). No entanto, avalia, em termos mais amplos, "que o negro na América é incontestavelmente um mal, da mesma forma que foi a escravidão uma peste social" (ibidem:19). Em outras palavras, coloca o escravo no mesmo plano da escravidão, como se o primeiro fosse o principal responsável pelos malefícios resultantes do trabalho servil.

Mas apesar do "problema negro", o diplomata percebe que os EUA já estavam se tornando um ator decisivo no cenário internacional. Toma, em especial, a Guerra entre Espanha e EUA em 1898 como prova "de que os Estados Unidos vão tornar-se uma grande potência colonial" (ibidem:459), Porto Rico já tendo sido anexado ao país, o que, imagina, logo ocorreria com Cuba. Diferente de outros latino-americanos, como Prado e Nabuco, não avalia, porém, que deveria ser motivo de preocupação o perigo de incorporação de toda a região aos EUA, até porque países fracos sempre poderiam ser anexados. Consequentemente, "proclamar receios de absorção é dar testemunho da própria impotência para os conflitos de civilização" (ibidem:453). 
Melhor, em contraste com a posição do autor de A Ilusão Americana, não vê a ascensão dos EUA com temor, mas como fato e, até mesmo, como uma possibilidade positiva. $\mathrm{O}$ imperialismo norte-americano seria, como costuma acontecer em tais situações, produto da sua grande produção agrícola e industrial, que não poderia ficar limitada ao seu mercado interno, mas, diversamente do que acontecera na Europa, não refletiria um excedente de população. Com o imperialismo, os EUA passariam a ter uma Marinha poderosa. Nessa orientação, o país passaria a assemelhar-se, cada vez mais, à Inglaterra, estabelecendo no Pacífico um domínio comparável ao que a Albion tivera no Mediterrâneo e no Mar Vermelho. Seria, além do mais, natural que, tanto por motivos comerciais como culturais, as duas potências anglo-saxãs formassem uma aliança.

Em compensação, seria o caso de verificar se os EUA, que nutririam a mesma concepção de direito e de liberdade da Inglaterra, se comportariam como sua antiga metrópole quando se tornassem uma potência colonial, permitindo uma autonomia relativa dos povos subjugados. Coerente com sua visão a respeito das raças, preocupa especialmente ao autor de Nos Estados Unidos saber se será "possível em Cuba ou Porto Rico entregar a direção dos negócios à parte educada da população espanhola e excluir dela os negros" (ibidem:502), que correspondem a uma proporção considerável da população das duas ilhas caribenhas, tendo sido especialmente numerosos entre os insurgentes que se levantaram contra o domínio espanhol. Significativamente, mais uma vez, a avaliação de Oliveira Lima das relações raciais em Cuba é oposta à de Prado. Se o segundo as toma como exemplo de convívio harmônico, o primeiro teme a possível preponderância negra.

Num sentido mais amplo, Nos Estados Unidos avalia que só se poderia ter verdadeira civilização na América sob a direção da "raça europeia". Na sua ausência, os povos do Continente seriam como que tragados pela degradação própria a seu ambiente. Portanto, mais do que o risco da anexação, o verdadeiro perigo que correriam "quase todos os nossos países latino-americanos, se o não salvarem a sã imigração europeia, com todas as consequências morais que comporta", seria o de passarem a figurar na "categoria geral das terras tropicais habitadas pelas raças inferiores, e para as quais está-se tornando preciso aviar a receita humanitária da dominação do povo mais apto para a colonização e o progresso" (ibidem:457).

DADOS - Revista de Ciências Sociais, Rio de Janeiro, vol. 61, nº 1, 2018 
Em outras palavras, o diplomata sugere que melhor opção do que o simples domínio colonial seria conseguir estabelecer boas relações com os EUA, como seria o próprio desejo do país. Nesse sentido, avalia que apesar da Conferência de Washington de 1889 não ter obtido resultados significativos, ela funcionaria como marco de aproximação entre as nações americanas.

No Brasil, desde a República, os EUA exerceriam verdadeiro fascínio, tendo passado a ser o grande modelo político do país. A Constituição de 1891, em especial, se inspirara diretamente na Constituição norteamericana. Nessa referência, Oliveira Lima apesar de defender, de maneira semelhante a Nabuco, que a lei orgânica de um país deveria ser idealmente o produto de seu desenvolvimento, como ocorreria na Inglaterra, ressalta que a Constituição brasileira seria um decalque da norte-americana. No entanto, ressalta que "copiar uma Constituição é uma coisa, aplicá-la [...] é outra" (1896:215) ${ }^{45}$.

Em termos gerais, a maior dificuldade em adotar as instituições de um outro país adviria das diferenças presentes entre as variadas sociedades. Assim, se nos EUA os governantes se identificariam com os governados, no Brasil aquele que deveria ser o soberano se encontraria "nas ruínas das senzalas, nos cortiços das cidades, nos campos do Sul e nas matas de seringueiras" (ibidem:230). Em resumo, "o povo não existe" (ibidem:13; ênfase no original). Portanto, o principal instrumento a ser empregado para se ter soberania popular e verdadeira República seria a educação, que deveria ter o papel de formar um povo ${ }^{46}$. Mais uma vez, o grande exemplo seriam os EUA, em que, como insistira Horace Mann, a educação popular teria um papel decisivo no que se tornara a nação norte-americana.

Em termos mais fortes, Veríssimo, fundador, com Lauro Sodré, do Clube Republicano do Pará, em A Educação Nacional, livro publicado em 1890 no seu estado natal, já ressaltara a importância da educação para se formar cidadãos para a República ${ }^{47}$. Num contexto em que o governo Deodoro criara um Ministério da Instrução Pública, no qual alojara o ex-ministro do Exército Benjamin Constant, principal propagandista do Positivismo entre militares, o paraense não deixa de acreditar nas possibilidades de reforma trazidas pela República ${ }^{48}$. Nesse sentido, argumenta que mudanças no governo não deveriam ser divorciadas de transformações igualmente profundas na educação, defendendo até que as segundas seriam mais importantes do que as primeiras: "para 
reformar e restaurar um povo, um só meio se conhece, quando não infalível, certo e seguro, é a educação, no mais largo sentido, na mais elevada acepção da palavra" (Veríssimo, 1906:41). Em outras palavras, a educação seria o melhor instrumento para criar algo como a opinião pública.

Seriam exemplos de povos que estariam se reformando pela educação a França da III República, desejosa de pôr fim aos motivos da derrota na Guerra Franco-Prussiana (1870), e a Itália pós-unificação, que precisaria efetivamente criar uma nação. Mas Veríssimo ressalta, em especial, como a educação nacional contribuiria para formar um sentimento comum nos $\mathrm{EUA}^{49}$. No entanto, aponta que, erroneamente, se tomava o ensino na república norte-americana como privado, quando ele estaria, na verdade, a cargo do Estado nos níveis primário e secundário, mesmo as universidades dependendo de generosas dotações de particulares. Em termos mais profundos, de maneira muito diferente do caso brasileiro, o ensino norte-americano, assim como as demais instituições do país, seguiriam os delineamentos lançados pelos puritanos no início da sua colonização.

De forma mais ampla, ainda em contraste com os EUA, onde, como teriam mostrado o francês Alexis de Tocqueville e o italiano Pasquale Villari, as instituições seriam o produto da democracia, no Brasil elas refletiriam o absolutismo. Desde o início das histórias dos dois países, a atitude austera dos puritanos contrastaria com a postura aventureira dos colonos ibéricos. Em resumo, as diferenças entre o país anglosaxão e o latino diriam respeito ao "clima, raça, situação geográfica, origem histórica, elementos de colonização, instituições fundamentais, tudo" sendo "ali diverso" (ibidem:176).

Portanto, Veríssimo considera, assim como Oliveira Lima, que mesmo que se pudesse aprender com a república norte-americana, não se poderia copiar suas instituições. Numa alusão à Guerra do Paraguai, avalia até que seria verdadeiro, nem que fosse por motivos errados, a alcunha de macacos que alguns povos irmãos nos deram: durante o Império, se copiaria a literatura, os costumes e até as modas francesas, ao passo que a política se inspiraria na Inglaterra; com a República, os EUA passariam a servir de grande exemplo. No entanto, de maneira similar a Prado, avalia que a razão do progresso da república norteamericana não se encontraria nas instituições adotadas, mas na abundância de terras e imigrantes e, principalmente, na raça que a coloniza-

DADOS - Revista de Ciências Sociais, Rio de Janeiro, vol. 61, nº 1, 2018 
ra. Prova da importância desse fator seria o sucesso do Canadá e da Austrália, também eles países anglo-saxões.

Mesmo assim, Veríssimo, ao avaliar a civilização norte-americana, confessa, usando quase as mesmas palavras de Rodó: "admiro-a, mas não a estimo" ${ }^{\prime 50}$. Os motivos que fariam com que não estimasse os EUA também são muito parecidos com aqueles do escritor sobre quem faz uma resenha dez anos depois: "tão excessivamente prática, tão colossalmente egoísta e tão eminentemente, perdoem-me a expressão strugorfolista (sic)" (ibidem:177). Igualmente como Prado, lembra de páginas pouco abonadoras da história norte-americana, como a escravidão - que, curiosamente, os escritores brasileiros avaliam numa chave menos severa no que se refere a seu próprio país - e de práticas condenáveis, como os linchamentos e a corrupção, supostamente generalizados nos EUA.

Mas sobretudo, como também ressaltariam os arielistas e Oliveira Lima, o país seria a pátria da "supremacia brutal das massas, aquele reino absoluto do número" (Veríssimo, 1906:178), o que criaria o pior dos despotismos: o da opinião pública. Seria ele que explicaria a mediocridade da sua vida nacional, incapaz de criar grande literatura. Também de maneira similar a argumentos depois utilizados, considera que todos esses motivos deveriam levar o Brasil a manter a sua originalidade, até porque "temos o direito de ser um astro soberano" e não "um mero e modesto satélite da república enorme" (ibidem:200).

Na primeira década republicana, Eduardo Prado, Joaquim Nabuco, Rui Barbosa, Manoel de Oliveira Lima e José Veríssimo envolvem-se numa acalorada polêmica a respeito do destino da nova forma de governo no país. Nesse debate, pensar o lugar do Brasil na América se torna uma questão central. Os monarquistas, Prado e Nabuco, alertam especialmente para o perigo de o país cair vítima da instabilidade que marcaria as repúblicas hispano-americanas, riscos que não deixam de preocupar a todos os autores. Ao mesmo tempo, Prado e Veríssimo veem o progresso dos EUA como uma miragem que o Brasil não poderia atingir, ressaltando que os dois países seriam muito diferentes, principalmente por motivos raciais e culturais. Prado, Nabuco e Veríssimo temem igualmente o imperialismo norte-americano, perigo que Oliveira Lima não enxerga ou até vê com bons olhos, mais preocupado que está com a degeneração da própria América Latina. 
Os cinco escritores, ao tratarem da América, enfrentam a questão democrática, entendida como tendência histórica irreversível. No entanto, é possível se perguntar, como faz Oliveira Lima, se no Brasil existe então soberania popular ou até mesmo povo. Se a resposta for negativa, será preciso se apostar na transformação ou mesmo na criação de um povo. Os principais instrumentos para tanto são a imigração e a educação, grande aposta de Veríssimo que o regime inaugurado em 1889 não levou suficientemente a sério. Em termos contrastantes, a democracia seria encarnada especialmente nos EUA, onde imperaria a opinião pública, e, à sua maneira, na América Latina caudilhista, em que líderes inescrupulosos se apoiariam em massas ignaras. Nesse sentido, a americanização confunde-se com a democratização e o caudilhismo, orientações que ganhariam força com a República. A referência à América Latina, em particular, indica que certos autores brasileiros iniciam, na primeira década republicana, um processo de aproximação conturbada - cheio de idas e vindas - do seu país com a região ${ }^{51}$. Nessa referência, como indica Baggio, “a identificação de brasileiros como latino-americanos é fluida, variável, mais ou menos presente dependendo das circunstâncias e do momento histórico" (2013:178).

Em termos mais amplos, tais oscilações identitárias não ocorrem apenas no Brasil; mesmo um país como o México, decisivo para a difusão da ideia de América Latina, variou bastante em sua atitude para com a região. Só a partir de 1915, quando Venustiano Carranza se torna presidente, num momento em que os EUA ainda não haviam reconhecido o governo revolucionário, é que se dá início a um intenso esforço de aproximação e uma verdadeira campanha propagandista destinada à América Latina (Yankelevich, 1995) ${ }^{52}$. Num sentido mais profundo, a própria ideia de América Latina variou consideravelmente desde que foi estabelecida, em 1856, por nativos da região vivendo então em Paris. Mesmo assim, ao longo desses mais de 150 anos, o contraste com os EUA tem sido um fator decisivo e constante para latino-americanos entenderem quem são.

Num sentido complementar, brasileiros, como Prado, Nabuco, Rui, Oliveira Lima e Veríssimo, passaram, desde a proclamação da República, a pensar, em grande medida, o Brasil com base no lugar que o país ocupa entre os EUA e a América Latina. Significativamente, estes escritores, apesar de todas as suas diferenças, também estiveram juntos na fundação, em 1897, da Academia Brasileira de Letras (ABL) ${ }^{53}$. 


\section{Bernardo Ricupero}

Nela, forjam um espaço relativamente autônomo de atuação para eles e outros membros da nova categoria de intelectuais que aparece então no Brasil (El Far, 2000). A criação da ABLé, em outro sentido, um sinal de que a distância entre esses membros da elite intelectual e política talvez não fosse tão grande assim.

No que nos interessa aqui, estes homens nutrem um misto de fascínio e temor pela democracia norte-americana e pelo caudilhismo hispanoamericano. Desse ponto de vista, mesmo quando invertem suas posições, como ocorre, na década seguinte, com os dois pernambucanos do grupo - Nabuco se convertendo num entusiasta do pan-americanismo, ao passo que Oliveira Lima se transforma num crítico contumaz da relação privilegiada com os EUA favorecida pela política externa do barão do Rio Branco - não deixam de compartilhar de uma certa perspectiva. De maneira mais ampla, desde a primeira década republicana, o Brasil é pensado na América, o que só pode ocorrer porque certos escritores brasileiros passaram então a se perguntar sobre o lugar do país no Continente.

(Recebido para publicação em 28 de Julho de 2016) (Reapresentado em 22 de Maio de 2017) (Aprovado em 30 de Outubro de 2017) 
A República e a Descoberta da América

\section{NOTAS}

1. "A Regeneração da América Latina", publicado originalmente no Jornal do Commercio, trata também de Peligros Americanos, do argentino A. Rodríguez, o artigo tendo sido reeditado em Homens e Cousas Estrangeiras, livro de 1902.

2. É verdade que já antes da proclamação da República a política externa brasileira privilegiara as questões do Prata, frequentemente em contexto de conflito. No entanto, ela não era acompanhada por uma preocupação identitária com os demais países da América. Estimularam a aproximação com o resto do Continente americano, ainda durante o Império, a Guerra do Paraguai (1864-1870) e a Abolição (1888).

3. Sérgio Buarque de Holanda indica, sugestivamente, que o americanismo chega mesmo à vestimenta: "o chapéu mole, de abas largas, que Quintino [Bocaiúva] ostentava, ao regressar de Buenos Aires, e que antes não fora de muito uso no Rio de Janeiro, logo se identificou no Império como sinal de adesão às novas ideias. Isso entre o elemento civil. Entre militares, embora neste caso não devesse traduzir forçosamente adesão manifesta ao republicanismo, distinguia Tobias Monteiro como resíduo de usos adquiridos no contato de seus companheiros de armas do Prata, a calça balão, irmã da bombacha, o rebenque preso ao pulso por uma corrente de prata, a cabeleira basta e oleada, o boné de lado" (Holanda, 1985:252).

4. Entre os republicanos brasileiros, a referência aos EUAé, como indica José Murilo de Carvalho (1990), especialmente forte para os fazendeiros de café paulistas, grandes defensores da federação, outros adeptos desta forma de governo visando especialmente a França. Mesmo assim, um dos primeiros símbolos do novo regime, a bandeira levada às ruas no 15 de novembro, mas que não perdurou, era inspirada na norteamericana, contando ela também com estrelas e listras, no caso, verde e amarelas.

5. Depois de Veríssimo, Holanda, já em 1920, e Vicente Licínio Cardoso, em 1923 e em obra póstuma publicada em 1937, voltam a tratar do opúsculo de Rodó. Outros que fizeram referência ao escritor uruguaio, são, já depois da Revolução de 1930, Manuel Bandeira e Silvio Junior. A primeira edição brasileira de Ariel é apenas de 1933 (ver Flores, 2006; Peden apud Rodó, 1988).

6. Esse período que Benedict Anderson (2005) chama de "globalização precoce" assiste, além do mais, não só à intensificação das trocas comerciais, mas também das intelectuais e políticas, estimuladas por novas invenções, como o telégrafo, o navio e o trem a vapor. Não por acaso, a consciência da debilidade do Império espanhol, revelada pela guerra de independência cubana, que estoura em 1895 e leva a se mobilizar a maior frota naval até então a cruzar o Atlântico, estimula, pouco depois, revolucionários filipinos também a se levantarem em armas. Nacionalistas periféricos, como o cubano José Martí e o filipino José Rizal, encontram, além do mais, parte de seu apoio mais decidido em anarquistas provenientes de diferentes países europeus.

7. Pelo menos desde que o francês Michel Chevalier publica, em 1836, Lettres sur l'Amérique du Nord, se pensa uma divisão análoga na América à existente na Europa entre o Norte e o Sul do Continente. Em resumo, se no Velho Mundo os povos setentrionais falariam línguas germânicas e professariam o protestantismo como religião, ao passo que os povos meridionais se expressariam por meio de línguas latinas e seriam católicos, também "os dois ramos, latino e germânico, são reproduzidos no Novo Mundo" (Chevalier, 1837:11). Igualmente, os primeiros a usarem, em 1856, o

DADOS - Revista de Ciências Sociais, Rio de Janeiro, vol. 61, nº 1, 2018 


\section{Bernardo Ricupero}

termo "América latina", o chileno Francisco Bilbao e o colombiano José María Torres Caicedo, contrastam, num sentido etnocultural, a região com os EUA, cuja ação imperialista já fizera com que o México perdesse quase metade de seu território, além de se fazer sentir fortemente na América Central. Ver Bilbao (1995); Chevalier (1837); Torres Caicedo (2006). Sobre o termo "América Latina", ver especialmente: Ardao (1993); Mignolo (2012); Phelan (1973); Rojas-Mix (1986).

8. Além do mais, há bons trabalhos mais gerais sobre a visão brasileira a respeito da América Latina, como o de Leslie Bethell (2010), e mais específicos sobre a maneira de entender a região por certos intelectuais, durante os primeiros anos do Império e da República, como os de Kátia Baggio (1998), Maria Lígia Coelho Prado (2001), Preuss (2011) e Helder Silveira (2003), mas não um estudo cujo foco seja como, na primeira década republicana, se entendeu o Brasil a partir do contraste entre a América Latina e os EUA. De certa maneira, esse período prepara o terreno para que, nos anos 1900, o Brasil procure a aproximação com os EUA no que Bradford Burns (1966) chamou de "aliança não escrita". Significativamente, as posições de alguns dos protagonistas do debate no início da República então se invertem: Nabuco passando a servir ao governo republicano como um defensor entusiasta do pan-americanismo, ao passo que Oliveira Lima, convertido à monarquia, defende a aproximação com a América hispânica.

9. Sinal disso são os documentos diplomáticos. Como indica Luís Cláudio Villafañe G Santos (2005), os Relatórios da Secretaria de Estado dos Negócios Estrangeiros (RNSE) do Império não usavam o termo "América Latina", mas expressões como "América", sugerindo a unidade do Continente, e, esporadicamente, "América do Sul". Só com a República, passa-se a utilizar o termo "América Latina".

10. Prado, rico herdeiro de uma das mais importantes famílias da burguesia cafeeira paulista, não demonstrara até então grande interesse por política, passando boa parte do seu tempo na Europa. Diferente da maior parte dos monarquistas, não tinha exercido funções importantes na política e nas letras do Império. Também num sentido contrastante, os irmãos mais velhos de Eduardo assumiram outras posições: Martinico foi, já, durante o Império, um republicano ardoroso e o monarquista Antônio se adaptou à nova situação política, como tantos outros "republicanos de última hora", convencidos que estavam de que o novo regime era um fato consumado. Sobre Prado, ver Levi (1977); Skidmore (1975). Sobre o monarquismo, ver Janotti (1986); Oliveira (1989).

11. Sobre a Revolta da Armada, ver especialmente Bandeira (1978); Bello (1964); Carone (1981); Costa (1979)

12. Prado, no exílio, chega a se tornar agente da Revolução na Europa. Ver Janotti (1986); Levi (1977).

13. Sobre a ação de Salvador de Mendonça, ver Pereira (2009).

14. As suspeitas de monarquismo são alimentadas pelas ligações com o Império de alguns dos protagonistas da Revolta da Armada, como Saldanha da Gama, e da Revolução Federalista, como Gaspar Silveira Martins. O contra-almirante, em particular, contribui para o temor de republicanos, explorado especialmente por Salvador de Mendonça, ao afirmar, em manifesto: "a lógica assim como a justiça dos fatos autorizaria que se procurasse à [sic] força das armas repor o governo do Brasil onde estava a 15 de novembro de 1889, quando num momento de surpresa e estupefação nacional 
ele foi conquistado por uma sedição militar, da que o atual governo não é senão uma continuação" (Saldanha da Gama apud Costa, 1979:97-98). Na verdade, os objetivos dos revoltosos são bastante díspares: Custódio de Mello diz bater-se em nome da Constituição republicana, que Floriano teria violado; Saldanha da Gama assume abertamente seu monarquismo, ao passo que os gaúchos são federalistas e parlamentaristas. Tais contradições se revelam decisivas para a derrota dos insurgentes.

15. Irritara-o, em especial, as concessões do chanceler do governo provisório, Quintino Bocaiúva, à Argentina referentes aos disputados territórios de Palmas (nomenclatura brasileira) ou Missões (nome argentino). Em começos de 1890, o ministro assinara com o chanceler argentino Estanislao Zeballos, em nome da fraternidade americana, um acordo pelo qual se dividia ao meio o território disputado. $\mathrm{O}$ acordo desencadeou oposição quase unânime, que se estendeu do Imperador exilado e os monarquistas aos "jacobinos". Finalmente, em 1891 seria rejeitado pela Câmara dos Deputados. Os monarquistas aproveitam o episódio para contrastar a iniciativa "ingênua" da República com a política externa do Império, supostamente capaz de salvaguardar os interesses nacionais, especialmente na estratégica região do Prata. Ver Cervo e Bueno (1992); Carone (1981); Janotti (1986); Ricupero (2017).

16. Segundo Prado, o Brasil teria sido ludibriado com o acordo. Concedeu isenção de impostos a diversas mercadorias norte-americanas importadas em troca de benefícios ao café e alguns tipos de açúcar exportados pelo país. No entanto, o café brasileiro não seria tarifado nos EUA desde 1875, o que faria com que possíveis impostos onerassem especialmente o consumidor norte-americano. Já os benefícios para o açúcar importado do Brasil logo foram estendidos para a Espanha, que ainda controlava Cuba e Porto Rico, fazendo com que as supostas vantagens desaparecessem como num passe de mágica.

17. Prado, como tantos outros escritores do final do século XIX ainda utiliza o adjetivo "latina" para se referir ao território situado ao sul do Rio Grande e não o substantivo "Latina".

18. Rodó, por sua vez, chega, em termos quase religiosos, a ter uma "visão de uma América deslatinizada por sua própria vontade, sem a extorsão da conquista, e regenerada logo à imagem e semelhança do arquétipo do Norte" (Rodó, 1957:221). Avalia que o pior de tal desenvolvimento seria abrir mão da própria personalidade que, como já defendera Cícero, seria o principal bem que se poderia possuir.

19. O franco-argentino Groussac enxerga, ao falar dos EUA, a existência de um verdadeiro abismo "entre povos produtores e consumidores de civilização". Os últimos chegariam "a possuir, em troca de seu solo virgem, todos os instrumentos da civilização". Mesmo assim, haveria uma "diferença, mais profunda ainda para o livro do que o recipiente de metal", já "que os civilizados compram o que os civilizadores elaboram" (Groussac, 1897:XXI). Igualmente como Darío e Groussac, a viagem aos EUA serve para Prado conformar uma imagem do país como bárbaro, especialmente em confronto com a civilizada Europa. De Chicago, que considera "a cidade mais brutal do mundo", confessa, em correspondência: "estou na realidade extenuado com a viagem e ansioso para ver-me livre deste país que é uma fornalha e onde para abrir-se a boca paga-se um dólar e outro para fechar-se. Decididamente o mundo é Paris" (Prado apud Barreto, 1916:187).

20. No entanto, o Brasil foi, entre os países latino-americanos, aquele em que os EUA contou com menor hostilidade durante a Guerra. Exemplo de uma posição mais céti-

DADOS - Revista de Ciências Sociais, Rio de Janeiro, vol. 61, nº 1, 2018 


\section{Bernardo Ricupero}

ca a respeito do conflito é a avaliação de Antonio Salles de que ele não passaria de uma "luta estoica, mas inútil de uma nação decadente contra a fatalidade histórica" (Salles, 1897:234).

21. A referência é a William McKinley, presidente dos EUA durante a Guerra pela independência de Cuba; a Robert Gascoyne-Cecil, Lord Salisbury, então secretário de Relações Exteriores do Reino Unido e ex-primeiro ministro conservador; e a John Lubbock, barão de Aveubry, arqueólogo e político liberal inglês.

22. Em termos mais profundos, percebe-se uma motivação conservadora por parte de Prado, como não deixou de indicar seu amigo português Eça de Queirós: "com o desaparecimento do Império ele temia o desaparecimento do velho Brasil, da sua sociedade esmerada e culta, dos seus costumes graves e doces, da sua disciplina social, da sua segurança legal, da sua harmonia econômica, da sua autoridade entre as nações de toda aquela ordem formosa que o erguia na América como representante mais alto da civilização latina" (Queirós, 1898:696).

23. A entrada do seu diário de 22 de outubro de 1893 indica que chega a pensar, narcisisticamente, numa nova missão que substituísse o "mandato da raça negra": "pobres países da América Latina! São os escravos que eu trataria de resgatar, se dispusesse dos elementos todos de civilização" (Nabuco, 2005:75).

24. Em sentido inverso, Magalhães de Azeredo toma o trabalho de Nabuco, escrito por um autor que confessara não conhecer bem o Chile, como indicação de que a atenção a temas americanos seria ainda excepcional entre brasileiros e prova de que "a nossa fraternidade é ainda platônica e estéril" (Azeredo, 1896:172).

25. Sinal da tranquilidade política que se acreditava prevalecer no Chile é o comentário feito por Eduardo Prado, apenas cinco anos antes da guerra civil, a respeito do país que então visitava: "quando um novo presidente recebe o poder, tem a certeza de que o transmitirá pacificamente ao seu sucessor" (Prado, 1902b:105).

26. O maior crítico do escravismo brasileiro chega a defender, de forma pouco crível, que "entre nós a política era acessível a todos; quase sem exceção, os nossos estadistas foram homens que se fizeram por si, sem nome de família, sem fortuna, sem relações no Paço" (Nabuco, 1895a:191). Admite apenas que o sucesso na carreira política poderia depender da boa vontade da "trindade saquarema", de Eusébio Queiroz, Rodrigues Torres e Paulino Soares de Sousa.

27. Em termos retóricos, Nabuco imagina que, antes de tirar a vida, Balmaceda possivelmente tenha contemplado a cordilheira dos Andes, identificando a paisagem com os princípios conservadores que o brasileiro defende: “talvez (...) ele viu na Cordilheira a imagem da antiga sociedade que pensara destruir, a sua formação áspera, sua elevação lenta, por último a glória, a cultura, a riqueza que lhe revestira os cimos, como essa neve brilhante. Que fora na vida dessa sociedade, ele, o seu partido, a guerra civil? Uma avalanche" (Nabuco, 1895a:177).

28. A resenha "A Revolução Chilena e a Questão da América Latina" também chama a atenção, em sentido contrário do que defendera Nabuco, para como no conflito entre Poder Executivo e Poder Legislativo a razão, em termos legais, estava com Balmaceda e não com o parlamento, já que a Constituição chilena estabelecia um presidencialismo forte. No entanto, o autor preferira dar mais atenção aos costumes, à constituição não escrita do Chile, que teriam estabelecido, ao longo do tempo, algo como um sistema parlamentar. 
29. Sobre a relação entre os dois livros, ver Alonso (2009a).

30. O cunhado de Nabuco, Hilário de Gouveia, chegou a ser preso durante a Revolta da Armada.

31. Contra o relato de Nabuco da Revolta da Armada, se coloca Felisberto Freire, que caracteriza a reação à subvelação como situação em que "irrompeu das entranhas da pátria toda a energia nacional com todas as forças intemeratas e puras, que despertavam agora para realizar a salvação da República" (Freire, 1896:IX). Rebate, em especial, o argumento de que a intervenção estrangeira teria favorecido as forças governistas, defendendo que a neutralidade de quase todas as potências envolvidas com o conflito teria sido simulada, elas, de fato, tendo favorecido os revoltosos. O ex-ministro da Fazenda de Floriano admite, porém, o papel decisivo dos EUA no desfecho da insurreição, apesar de insistir em que a ação de sua força naval não teria violado a soberania brasileira, sendo plenamente justificada pelo direito internacional.

32. Nessa referência, Prado desejou, em 1896, que Nabuco se tornasse redator-chefe de $O$ Commercio de São Paulo, folha que comprou para fazer propaganda da causa monarquista. Antes, Nabuco anotou em seu diário, em 5 de dezembro de 1893, quando teve notícia da publicação do trabalho de seu amigo: "A ilusão americana, o livro de Eduardo Prado, que eu tantas vezes lhe disse que ia escrever, o que será? [...] Expus-lhe [...] por vezes as linhas gerais e disse-lhe que desejava que alguém o fizesse. É um gênero de propaganda em que há muito que fazer" (Nabuco, 2005:88).

33. Diversos autores chamaram a atenção para a questão. Ver, por exemplo, Alonso (2009b); Costa (1979); Janotti (1986); Stein (1964).

34. Fábio Santos chega a considerar, num sentido lato, que "o Brasil também apresentou a sua própria corrente 'arielista', à medida que autores como Joaquim Nabuco e Eduardo Prado reagiram à implantação dos primeiros regimes militares republicanos" (Santos, 2003:81). Também Levi (1977) e Baggio (1998) sugerem semelhanças entre A Ilusão Americana e Ariel.

35. Chega a elogiar A Ilusão Americana, que considera ser "opúsculo absolutamente novo no assunto, em que, como repositório de verdades ignoradas, é o mais oportuno serviço ao Brasil" (Barbosa, 1896:41-42). Em termos doutrinários, o ex-deputado baiano é particularmente próximo do ex-deputado pernambucano, apesar de a ênfase do segundo ser na reforma social, ao passo que o primeiro favorece a reforma política. Ver Lynch (2008).

36. Rui se afastou de Floriano, a quem chegara a ser próximo, devido à remoção de um aliado do governo da Bahia. A partir daí, dedicou-se, com afinco, à oposição ao governo "ditatorial", tendo se tornado um dos proprietários do Jornal do Brasil, folha originalmente monarquista fundada por Rodolfo Dantas e Nabuco. Chegou a impetrar diversos habeas corpus em favor de perseguidos pelo governo. Em especial, pouco antes de estourar a Revolta da Armada, pedira no Supremo Tribunal Federal um habeas corpus para o almirante e ex-ministro Eduardo Wandenkolk e outros que tinham tomado no porto de Buenos Aires o navio Júpiter em apoio à Revolução Federalista. Iniciativas como essas fizeram com que florianistas suspeitassem que o jurista baiano fosse um dos líderes da Revolta da Armada e o levaram a se exilar em Londres, antes tendo vivido alguns meses em Buenos Aires e Lisboa. Ver Gonçalves (2000); Ré (2016).

DADOS - Revista de Ciências Sociais, Rio de Janeiro, vol. 61, no 1, 2018 


\section{Bernardo Ricupero}

37. Já Domingo Faustino Sarmiento sugerira a afinidade. Assim como O Espírito das Leis relaciona a Ásia, com seus espaços intermináveis, ao despotismo, Facundo associara a Argentina, do pampa que não acaba, ao caudilhismo. Num caso como no outro, "o terror é um meio de governo" (Sarmiento, 1988:221). Em Cartas de Inglaterra, Rui cita Sarmiento, Juan Bautista Alberdi e o fundador do "revisionismo" argentino, Adolfo Saldías, mas baseia sua análise do caudilhismo, sobretudo no relato do historiador liberal Mariano Pelliza. Sobre uma certa imagem “oriental” do caudilhismo, ver Altamirano e Sarlo (1997).

38. Em 1895, monarquistas paulistas, como João Mendes de Almeida e Eduardo Prado, organizaram um partido. Contudo, ele não chegou a ter maior expressão.

39. Sobre o paulista, afirma: "um panfletário de grande talento, o sr. Eduardo Prado, escreveu um volume em que condena in limine toda história, instituições, política e costumes dos Estados Unidos" (Lima, 1899:372). Sobre o pernambucano, diz: "o sr. Joaquim Nabuco defendeu muito habilmente a tese, bastante paradoxal, que esta intervenção das divisões estrangeiras foi em tudo vantajosa para o governo legal" (Lima, 1896:35). Com base em posições como essas, há quem considere, como Teresa Malatian (2008), que os dois livros refletem a condição de diplomata de seu autor que, em quase missão oficial, buscaria legitimar o novo governo republicano.

40. Na mesma linha, avalia, posteriormente, que a independência produzira um quadro pouco animador na América: "uma única nação organizada, os Estados Unidos; um grande corpo amorfo, [...], o Brasil; e uma dúzia de estilhaços dos vice-reinados espanhóis, cuja história é monotonamente agitada, e nas quais generais, padres, aventureiros e mestiços dançavam uma sarabanda doida e sangrenta em redor do bezerro de ouro coberto com barrete frígio da Liberdade" (Lima, 1899:365).

41. Relativas exceções seriam o Chile e a Argentina, países para onde, não por acaso, afluía significativa imigração europeia.

42. Segundo o escritor franco-argentino, a civilização norte-americana, assim como o animal pré-histórico, seria "tão excessiva e gigantesca quanto incompleta e provisória" (Groussac, 1897:310). Também José Martí (1997), ao descrever a grandiosidade da ponte do Brooklyn, a comparara a um mamute.

43. Oliveira Lima chega a se perguntar sobre a possibilidade de os multimilionaires constituírem uma aristocracia nessa nova democracia. No entanto, lembra que não possuiriam nem tradições, nem obrigações hereditárias.

44. No entanto, não tem uma avaliação muito positiva dos imigrantes que chegam ao Brasil, supostamente vindos "dos países mais ignorantes e atrasados da Europa" (Lima, 1899:452).

45. Em tom mais otimista, Medeiros de Albuquerque (1896), em resenha a Sept Ans de République au Brésil, avalia que também os norte-americanos, inspirando-se principalmente em Locke e Montesquieu, teriam sabido adaptar certas instituições ao seu país. O mesmo estaria em vias de ocorrer no Brasil.

46. A educação é, de maneira geral, central para o republicanismo. Modernamente, Montesquieu considera que "é no governo republicano que se tem necessidade de toda a força da educação" (Montesquieu, 1973:62), Rousseau, por sua vez, afirma: "não basta dizer aos cidadãos: sejam bons; é preciso ensiná-los a sê-lo" (Rousseau, 2006:99).

47. O livro tem, em 1906, uma segunda edição no Rio de Janeiro. 
48. No mesmo sentido, funda e dirige, em Belém, entre 1884 e 1890, o Colégio Americano, em que introduzira modernos métodos pedagógicos. Chega a ser, em 1891, diretor da Instrução Pública de seu estado, experiência decepcionante que contribui para seu distanciamento da República. De maneira reveladora, como aponta Barbosa (1974), outros membros da "geração de 1870", como Tobias Barreto, Araripe Júnior, Rocha Lima e Capistrano de Abreu, também criaram escolas.

49. Como sinal de que faltaria tal consciência no Brasil, nota que em Belém, assim como em outras capitais, seria mais fácil encontrar obras estrangeiras do que brasileiras.

50. Rodó, por sua vez, afirma: "e por minha parte, já vês que, mesmo que não lhes ame, admiro-os" (Rodó, 1957:230). Já Jean Franco (1994), Roberto Fernandez Retamar (2004), Baggio (1998) e Barbosa (1974) chamaram a atenção para a semelhança das considerações do escritor uruguaio e do crítico paraense a respeito dos EUA.

51. Em outro sentido, julga Bethell que o Brasil passou a fazer parte da América Latina “quando a 'América Latina' se tornou 'Latin America', por assim dizer, quando os EUA, e por extensão a Europa e o resto do mundo, começaram a encarar o Brasil como parte de uma região chamada de Latin America, a partir do início dos anos 1920 e 1930, mas especialmente durante a Segunda Guerra e a Guerra Fria" (Bethell, 2010:474). De forma diversa, Preuss entende que por volta da década de 1900, “membros da elite brasileira tinham passado a se perceber, e também à sua nação, como parte da América Latina" (2011:28). Estes momentos são, sem dúvida, chaves na aproximação do Brasil com a América Latina, mas se incluem num fluxo de tempo complexo, no qual não faltam contradições, avanços e recuos, sendo difícil apontar datas precisas e definitivas.

52. Tal postura contrasta com a atitude dominante durante o período anterior do Poffiriato (1876-1911), voltada preferencialmente para a Europa, e a orientação muito posterior de aproximação com os EUA, cujo marco foi a assinatura, em 1992, do Acordo Norte-Americano de Livre Comércio, NAFTA na sigla em inglês. Pode-se, assim, especular que a hostilidade do governo Donald Trump para com o México terá, mais uma vez, impacto sobre a identidade do país.

53. A iniciativa da criação da ABL parte de Machado de Assis e literatos ligados à Revista Brazileira. Assim, o diretor da revista, Veríssimo, mas também os escritores já consagrados, Nabuco e Rui Barbosa, estão entre os 30 fundadores da Academia. Os mais jovens, Prado e Oliveira Lima, são, por sua vez, escolhidos membros em eleição complementar, realizada logo depois da fundação, a fim de que a Academia brasileira passasse a ter o mesmo número de membros, 40, da Academia Francesa.

DADOS - Revista de Ciências Sociais, Rio de Janeiro, vol. 61, nº 1, 2018 


\section{Bernardo Ricupero}

\section{REFERÊNCIAS BIBLIOGRÁFICAS}

ALENCAR, José Almino de. (2008), “Posfácio”. Balmaceda. São Paulo, Cosac Naify. . (2009), “Joaquim Nabuco: A História em Primeira Pessoa”. Revista USP, no 83, pp. $42-51$.

ALONSO, Angela. (2009a), "A Década Monarquista de Joaquim Nabuco". Revista USP, no 83 , pp. 52-63.

(2009b), “Arrivistas e Decadentes: O Debate Político-Intelectual Brasileiro na Primeira Década Republicana". Novos Estudos CEBRAP, no 85, pp. 131-148.

ALTAMIRANO Carlos; SARLO, Beatriz. (1997), Ensayos Argentinos: De Sarmiento a la Vanguardia. Buenos Aires, Compañía Editora Espasa Calpe Argentina.

ANDERSON, Benedict. (2005), The Age of Globalization: Anarchists and the Anti-colonial Imagination. London, Verso.

ANSALDI Waldo; FUNES, Patrícia. (1994), “Patología y Rechazos. El Racismo como Factor Constitutivo de la Legitimidade Política y la Cultura Política Latinoamericana". Cuicuilco, no 2, pp. 193-229.

ARDAO, Arturo. (1993), América Latina y la Latinidad. México, UNAM.

AZEREDO, Carlos Magalhães de. (1896), “O Espírito Americano”. Revista Brazileira, t. v. pp. 169-176.

BAGGIO, Kátia. (1998), A Outra América: A América Latina na Visão dos Intelectuais Brasileiros das Primeiras Décadas Republicanas. Tese (Doutorado em História), Universidade de São Paulo, São Paulo.

(2013), "Brasil e Hispano-América: Representações e Trocas Intelectuais", in E. F. Dutra (org.), O Brasil em Dois Tempos: História, Pensamento Social e Tempo Presente. Belo Horizonte, Autêntica, pp. 167-183.

BANDEIRA, Moniz. (1978), Presença dos Estados Unidos no Brasil. Rio de Janeiro, Civilização Brasileira.

BARBOSA, João Alexandre. (1974), A Tradição do Impasse: Linguagem da Crítica e Crítica da Linguagem em José Veríssimo. São Paulo, Ática.

. (1986), "Introdução", in J. Veríssimo: Cultura, Literatura e Política na América Latina. São Paulo, Brasiliense.

BARBOSA, Rui. (1896), Cartas de Inglaterra. Rio de Janeiro, Typographia Leuzinger.

BARRETO, Plínio. (1916), “Eduardo Prado e seus Amigos (Cartas Inéditas)”. Revista do Brasil, no 2 .

BELLO, José Maria. (1964), História da República do Brasil. São Paulo, Companhia Editora Nacional.

BETHELL, Leslie. (2010), "Brazil and Latin America". Journal of Latin American Studies, vol. 42, no 3, pp. 457-485.

BILBAO, Francisco. (1995), “Iniciativa de la América. Idea de un Congreso Federal de las Repúblicas", in L. Zea (org.), Fuentes de la Cultura Latino-americana. México, FCE.

BURNS, Bradford. (1966), The Unwritten Aliance. Nova York: Columbia University Press. 
CARONE, Edgard. (1981), A Primeira República: 1889-1930. v. II. São Paulo: Difel.

CARVALHO, José Murilo de. (1990), A Formação das Almas: O Imaginário da República no Brasil. São Paulo, Companhia das Letras.

CERVO, Amado; BUENO, Clodoaldo. (1992), História da Política Exterior do Brasil. São Paulo, Editora Ática.

CHEVALIER, Michel. (1837), Lettres sur l'Amérique du Nord. Bruxelles, Societé Belge de Librairie.

COLLIER, Simon; SATER, William F. (1996), A History of Chile. Cambridge, Cambridge University Press.

COSTA, Emília Viotti da. (1979), Da Monarquia à República: Momentos Decisivos. São Paulo, Livraria Editora Ciências Humanas.

EL FAR, Alessandra. (2000), A Encenação da Imortalidade. Rio de Janeiro, Fundação Getulio Vargas.

FAORO, Raymundo. (1991), Os Donos do Poder. Rio de Janeiro, Editora Globo.

FERNANDES, Maria Fernanda Lombardi. (2006), “Os Republicanos e a Abolição”. Revista de Sociologia \& Política, no 27, pp. 181-195.

FERNANDEZ RETAMAR, Roberto. (2004), Todo Calibán. Buenos Aires, Clacso.

FLORES, Maria B. R. (2006), “O Mito de Caliban na Interpretação do Brasil acerca do Americanismo na República Velha Brasileira”. Diálogos Latino-Americanos, no 11, pp. 50-71.

FRANCO, Jean. (1994), An Introduction to Spanish-American Literature. Cambridge, Cambridge University Press.

FREIRE, Felisberto. (1896), História da Revolta de 6 de Setembro de 1893. Rio de Janeiro, Editores Cunha \& Irmãos.

GONÇALVES, João F. (2000). Rui Barbosa: Pondo as Ideias no Lugar. Rio de Janeiro, Fundação Getulio Vargas.

GROUSSAC, Paul. (1897), Del Plata al Niagra. Buenos Aires, La Biblioteca.

HOLANDA, Sérgio Buarque de. (1985), História Geral da Civilização Brasileira: Do Império à República. São Paulo, Difel, t. II, vol. 7.

JANOTTI, Maria de Lourdes. (1986), Os Subversivos da República. São Paulo, Brasiliense.

LESSA, Renato. (1988), A Invenção Republicana. São Paulo, Vértice.

LEVI, Darrell E. (1977), A Família Prado. São Paulo, Cultura 70.

LIMA, Manoel de Oliveira. (1896), Sept Ans de République au Brésil. Paris, Librairie de la "Nouvelle Revue".

__. (1899), Nos Estados Unidos: Impressões Políticas e Sociais. Leipzig, F. A. Brockhaus.

LYNCH, Christian. (2008), "A Primeira Encruzilhada da Democracia Brasileira: Os Casos de Rui Barbosa e de Joaquim Nabuco". Revista Sociologia \& Política, vol. 16, no suplementar, pp. 113-125.

. (2012), “O Império é que Era República: A Monarquia Republicana de Joaquim Nabuco". Lua Nova, no 85, pp. 277-311.

DADOS - Revista de Ciências Sociais, Rio de Janeiro, vol. 61, nº 1, 2018 


\section{Bernardo Ricupero}

MALATIAN, Teresa. (2008), “Oliveira Lima nos Estados Unidos”. História Revista, no 2, pp. 497-507.

MANIFESTO DE 1870. (1890), “Manifesto de 1870”, in J. C. Teixeira, A República Brazileira. Rio de Janeiro, Imprensa Nacional.

MARTÍ, José. (1997), Nuestra América. Caracas, Biblioteca Ayacucho.

MIGNOLO, Walter. (2012), The Idea of Latin America. Malden, Blackwell.

MONTESQUIEU, Charles Louis de. (1973), Do Espírito das Leis. São Paulo, Abril Cultural.

NABUCO, Joaquim. (1895a), Balmaceda. Rio de Janeiro, Typographia Leuzinger. (1895b), A Intervenção Estrangeira durante a Revolta de 1893. Rio de Janeiro, Typographia Leuzinger.

_ (1949), Cartas a Amigos. São Paulo, Instituto Progresso Editorial.

(2005), Diários. Rio de Janeiro, Topbooks.

NOGUEIRA, Marco Aurélio. (2010), O Encontro de Joaquim Nabuco com a Política: As Desventuras do Liberalismo. São Paulo, Paz e Terra.

OLIVEIRA, Lúcia Lippi. (1989), “As Festas que a República Manda Guardar". Estudos Históricos, no 4, pp. 172-189.

PEREIRA, Gabriel. (2009), A Diplomacia da Americanização de Salvador de Mendonça. São Paulo, Cultura Acadêmica.

PHELAN, John. (1973), "El Origen de la Idea de América". Latinoamérica. Cuadernos de Cultura Latinoamericana, no 31, pp. 3-21.

PRADO, Eduardo. (1895), A Ilusão Americana. Paris, Armand Colin et Cie.

__ (1898), "A Hespanha”. Revista Moderna, no 19, pp. 597-599.

(1902a), Os Fastos da Ditadura Militar no Brasil. São Paulo, Escola Tipográfica Salesiana.

. (1902b), Viagens: América, Oceânia e Ásia. São Paulo, Escola Typographica Salesiana.

PRADO, Maria Lígia Coelho. (2001), “O Brasil e a Distante América do Sul”. Revista de História, no 145, pp. 127-149.

PREUSS, Ori. (2011), Brazilian Views of Spanish America and Themselves, 1865-1912. Madrid, Iberoamericana.

QUEIRÓS, Eça de. (1898), “Eduardo Prado”. Revista Moderna, no 22, pp. 693-699.

RÉ, Flávia Maria. (2016), Ideias em Ação. Liberalismo e Reforma no Pensamento Político de Rui Barbosa. Tese (Doutorado em Ciência Política), Universidade de São Paulo, São Paulo.

REVISTA BRAZILEIRA. (1898), Bibliographia. Revista Braziliense, t. XIII, pp. 128.

RICUPERO, Rubens. (2017), A Diplomacia na Construção do Brasil. Rio de Janeiro, Versal.

RODÓ, José Enrique. (1957), Obras Completas. Madri, Aguilar.

(1988), Ariel. Tradução e notas de Margaret Peden. Austin, University of Texas Press. 
ROJAS-MIX, Miguel. (1986), “Bilbao y el Hallazgo de América Latina: Unión Continental, Socialista y Libertaria...". Caravelle. Cahiers du Monde Hispanique et Luso-Brésilien, vol. 46, pp. 35-47.

ROUSSEAU, Jean Jacques. (2006), O Contrato Social. São Paulo, Martins Fontes.

SALLES, Antonio. (1897), “A Questão Cubana”. Revista Brazileira, t. XI, pp. 227-234.

SANTOS, Fábio M. (2003), “A Querela dos Heróis: Liderança Política e Ethos Americano em Oliveira Lima e José Enrique Rodó". História, no 2, pp. 79-98.

SANTOS, Luís Cláudio Villafañe G. (2005), “A América do Sul no Discurso Diplomático Brasileiro". Revista Brasileira de Política Internacional, no 48, pp. 185-204.

SARMIENTO, Domingo Faustino. (1988), Facundo. Madrid, Alianza.

SILVEIRA, Helder Gordim da. (2003), Joaquim Nabuco e Oliveira Lima: Fases de um Paradigma Ideológico da Americanização nas Relações Internacionais do Brasil. Porto Alegre, EDIPUCRS.

SKIDMORE, Thomas. (1975), "Eduardo Prado: A Conservative Nationalist Critic of the Early Brazilian Republic, 1889-1901". Luso-Brazilian Review, no 2, pp. 149-161.

STEIN, Stanley. (1964), “A Historiografia do Brasil 1808-1889”. Revista de História, no 29.

TORRES CAICEDO, José María. (2006), “Las Dos Américas”. El Correo de Ultramar. Paris, 1857. Disponível em: <http: filosofia.org>. Consultado em 25/7/2016.

VERÍSSIMO, José. (1895), “A Revolução Chilena e a Questão da América Latina”. Revista Braziliense, t. III, pp. 108-121.

. (1902), Homens e Cousas Estrangeiras. Rio de Janeiro, R. Garnier, Livreiro-Editor, vol. I.

. (1906), A Educação Nacional. Rio de Janeiro, Livraria Francisco Alves.

YANKELEVICH, Pablo. (1995), “Las Campañas pro México: Estrategias Publicitarias Mexicanas en América Latina (1916-1922)". Cuadernos Americanos. Nueva Época, ano IX, vol. 1, no 49, pp. 79-95.

DADOS - Revista de Ciências Sociais, Rio de Janeiro, vol. 61, nº 1, 2018 


\section{Bernardo Ricupero}

RESUMO

A República e a Descoberta da América: Nova Forma de Governo e Mudança Identitária no Brasil da Década de 1890

$\mathrm{O}$ artigo procura indicar como, na primeira década republicana, ganha força uma maneira de entender o Brasil numa referência americana mais ampla. Para tanto, examino como, no momento de passagem do Império para a República, certos autores monarquistas, como Eduardo Prado e Joaquim Nabuco, e escritores mais próximos da República, como Rui Barbosa, Manoel de Oliveira Lima e José Veríssimo, entendem o lugar do seu país na América. Busca-se, em especial, analisar como intelectuais brasileiros passam a se movimentar entre os EUA e a América Latina até como maneira de entenderem sua própria identidade e enfrentarem, principalmente, a questão da democratização. Finalmente, o artigo aponta que muitas de suas preocupações os aproximam de intelectuais hispano-americanos do período, o que pode ser tomado como sinal de que o Brasil do final do século XIX enfrenta ordem de problemas comparável ao resto da América Latina, em particular, o novo desafio representado pela ascensão dos EUA como potência mundial.

Palavras-chave: Brasil; América; Império; República; democracia; identidade

\section{ABSTRACT}

The Brazilian Republic and its Discovery of the Americas: The New Form of Government and Brazil's Shift in Identity in the 1890s

The following article seeks to identify how Brazil came to be understood in a wider American context in the first decade of the First Brazilian Republic. To do so, it examines how certain Monarchist authors such as Eduardo Prado and Joaquim Nabuco and more Republican writers such as Rui Barbosa, Manoel de Oliveira Lima, and José Verissimo, viewed Brazil's role in the Americas in the former's transition from an empire to a republic. A particular focus is placed on analyzing how Brazilian intellectuals came to move between the US and Latin America as a means of understanding their own identity, mainly grappling with the issue of democratization. Finally, the article reveals how many of their concerns align them with the period's Hispanic-American intellectuals, reflecting how Brazil faced a series of problems at the end of the nineteenth century comparable to those experienced by the rest of Latin America, particularly in light of the fresh challenge posed by the rise of the US as a world power.

Key words: Brazil; the Americas; Empire; First Brazilian Republic; democracy; identity 


\section{RÉSUMÉ}

La République Brésilienne et sa Découverte de l'Amérique: Nouvelles Formes de Gouvernement et Transformations Identitaires dans le Brésil des Années 1890

Cet article cherchera à montrer comment, lors de la première décennie républicaine, s'est progressivement imposée une façon de voir le Brésil dans un contexte américain plus ample. À cette fin, nous avons examiné de quelle manière, au moment du passage de l'Empire à la République, certains auteurs monarchistes, comme Eduardo Prado et Joaquim Nabuco, et écrivains plus proches de la République, tels que Rui Barbosa, Manoel de Oliveira Lima et José Veríssimo, entendaient la place de leur pays en Amérique. On cherchera en particulier à analyser de quelle façon les intellectuels brésiliens ont commencé à voyager entre les États-Unis et l'Amérique latine, y compris comme une manière de mieux comprendre leur propre identité et $\mathrm{d}^{\prime}$ affronter plus spécifiquement la question de la démocratisation. Finalement, cet article montrera que nombre de leurs préoccupations finirent par les rapprocher des intellectuels hispano-américains de la même période, ce que l'on peut interpréter comme un signal de ce que le Brésil de la fin du XIX ${ }^{e}$ siècle affrontaient finalement des problèmes comparables à ceux du reste de l'Amérique latine, et en particulier le défi que représentait l'ascension des États-Unis en tant que grande puissance mondiale.

Mots-clés: Brésil; Amérique; Empire; République; démocratie; identité

\section{RESUMEN}

La República y el Descubrimiento de América: La Nueva Forma de Gobierno y el Cambio de Identidad de Brasil en la Década de 1890

El artículo busca hacer hincapié en el hecho de que, durante la primera década republicana, ganó fuerza una forma de entender Brasil influida por una referencia más amplia a América como continente. Para ello, examino la forma en que, en el momento del paso del imperio a la república, ciertos autores monarquistas, como Eduardo Prado y Joaquim Nabuco, y escritores más cercanos a la república, como Rui Barbosa, Manoel de Oliveira Lima y José Veríssimo, perciben el lugar que ocupa su país en América. Se busca, en especial, analizar de qué manera algunos intelectuales brasileños comienzan a vivir a caballo entre Estados Unidos y América Latina como forma de entender su propia identidad y afrontar, principalmente, la cuestión de la democratización. Por último, el artículo señala que muchas de sus preocupaciones los acercan a intelectuales hispanoamericanos de la época, lo que puede ser tomado como indicio de que el Brasil de finales del siglo XIX afrontaba una orden de problemas comparable al resto de América Latina, en particular, el nuevo desafío representado por la ascensión de Estados Unidos como potencia mundial.

Palabras clave: Brasil; América; império; república; democracia; identidad 